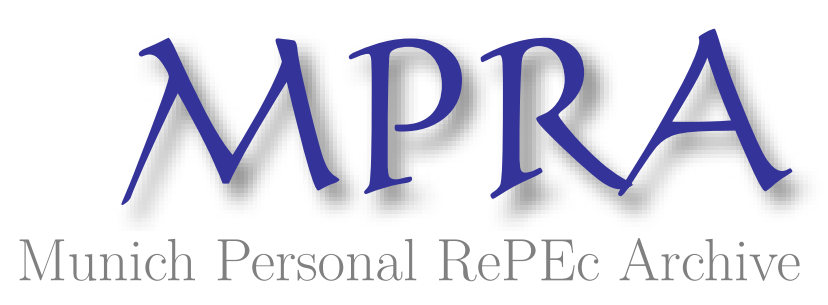

\title{
Unemployment and Welfare State: What do the Data Tell Us?
}

DING, HONG

12 October 2012

Online at https://mpra.ub.uni-muenchen.de/41921/

MPRA Paper No. 41921, posted 31 Jan 2014 13:17 UTC 


\title{
Unemployment and Welfare State: What do the Data Tell Us?
}

\author{
Hong Ding ${ }^{1}$
}

\begin{abstract}
The aim of this paper is to analyze the relationship between welfare expenditure by government and unemployment outcomes. Using a panel of 34 OECD countries from 1980 to 2010 and a two-way fixed effect model for panel data subject to endogeneity test and persistence test, the results of the paper suggest that total welfare expenditure as a percentage of GDP has a statistically significant positive impact on unemployment outcomes (total unemployment, long-term unemployment and youth unemployment). Among the four major components of national welfare expenditure, only income support and pension benefit are found to have the significant positive effect on all unemployment outcomes, public expenditure on health services has marginally significant positive impact on total unemployment rate, but not on long-term unemployment rate and youth unemployment rate and public social expenditures on other social services provided by government have no significant impact on unemployment. The econometric estimation results also provide evidence to support the hypothesis that one channel through which public social expenditure impacts unemployment is investment rate and the hypothesis that immigration can decrease a nation's total unemployment rate.
\end{abstract}

\footnotetext{
${ }^{1}$ E-mail: kevinding66@gmail.com
} 


\section{INTRODUCTION}

The relationship between welfare expenditure of government and unemployment rate was not given full investigation despite huge literature on the relationship between labor market institutions and unemployment. Although these two areas of study are closely linked to each other, the examination of the former is more fundamental: what is the economic impact of welfare state in terms of unemployment?

The impact of welfare state on economy is a long-standing debate. For decades, the economic impact of Europe's socialist (or "social democratic") welfare state has been fiercely debated among economists and politicians of left wing and right wing. If econometric studies on this impact could be based on randomized experimental data like clinical trials, such debate would never emerge. Unfortunately, facing only observational data, with very little opportunity of applying "natural experiments", the only option to get valid (consistent) econometric estimation is to use instrumental variable (IV), at least for endogeneity test and fixed effect model for panel data to control for country-specific heterogeneity or country-common global trend. Many econometric issues may bias the estimation of the effects of welfare spending measures on growth. As a result, the findings of previous empirical literature are mixed and inconclusive. The following section on literature review will show such problems in some previous econometric studies on the relationship between labor market performance and welfare state.

\section{BASIC THEORY AND LITERATURE REVIEW}

Generally, economic theory concerning the economic role of government has never reached consensus between Keynesian economists and Hayek school economists. What is the impact of government welfare spending in the short run? As Disney (2000) summarized, in a Keynesian setting, a tax-financed increase in welfare spending should have a modest expansionary impact on employment and output, so long as there are spare resources. In a static Neoclassical model, however, such public spending can completely displace private spending, so labor supply may depend on the net-of-tax replacement rate of earnings to out-of-work benefits. Atkinson (1995) also emphasized the importance of this benefit replacement rate (BRR) to unemployment and his imperfect labor market 
model shows that the effect of unemployment insurance on employment depends on the level of BRR and extent of benefit coverage.

Alesina and Perotti (1994) used a general equilibrium, two-country model with exportables, importables and nontradables to study redistribution across different types of agents in a world characterized by the presence of labor unions and distortionary taxation. They reveal that an increase in transfers to, say, retirees, financed by distortionary taxation, can generate a loss of competitiveness (defined as an increase in relative unit labor costs for tradable goods), an appreciation of the relative price of nontradables, and a decrease in employment in all sectors of the domestic economy.

On the other hand, Ljungqvist and Sargent (1995) constructed a search model where the government both provides liberal unemployment insurance and taxes labor at high progressive tax rates. They showed how progressive income taxation can counteract a high unemployment rate under generous unemployment insurance. In particular, high marginal taxes reduce workers' incentives to switch jobs in response to changing economic opportunities. This lower labor mobility reduces unemployment but at the cost of a less efficient labor allocation. In short, their theory does not indicate whether the net effect of unemployment insurance and income tax is positive or negative.

This paper is not about this theoretical debate, but on in-depth investigation of empirical evidences on the economic impacts of welfare states on employment in terms of public social welfare expenditures. Despite huge literature on the relationship between welfare spending and economic growth in terms of either level or growth rate of GDP or per capita GDP (see for example, Grier and Tullock (1989), Atkinson (1995), Agell et al. (1997), Beraldo et. al. (2009)), research on whether expenditure on welfare benefit programs in welfare state affects unemployment is not plentiful, surprisingly, particularly in face of great gap in average unemployment rate between EU nations and the US since late 1970s. Disney (2000) summarized five previous studies on macroeconomic evidence on tax and welfare policy and unemployment, but most of them concern tax policy variables (tax wedge or tax rate) and benefit replacement rate rather than specifically addressing the economic effect of welfare spending rate.

More generally, Atkinson's book (1995) argues that there is very little correlation between economic performance and welfare expenditure. Headey et al. (2000) also 
provided empirical evidence based on the economic performance of the United States, Germany and the Netherlands to support the view that there is no necessary trade-off between economic efficiency and a generous welfare state. Lindert (2003) even directly claimed that welfare state is a free lunch because there is no clear net GDP cost of high tax-based social spending on GDP. However, some econometric problems in his empirical findings cast doubt on validity of his econometric estimations. For example, he used two-stage-least-square (2SLS) estimation for the regression of per capita GDP growth in which the instrumental variables (IVs) he used for social spending and tax rates are age distribution, voter turnout rates, average income, religion, ethnic fractionalization, and openness to trade. It seems that we can have sufficient reasons to suspect exgoeneity of these IVs for at least some of them are almost certain to be correlated to unobservable or omitted potential determinants of income growth. For example, a country with higher proportion of youth, and higher openness to international trade tends to have higher growth. Also, the effect of religion on economy is widely accepted (see for example, Barro, McCleary (2003)). Average income, of course receives feedback effect from GDP growth rate. Endogenous explanatory variable(s) may lead to bias, but if instrument variable is not truly exogenous, the IV estimate's bias is even larger than OLS estimate. Similar problems may also exist in other findings of no correlation between growth and welfare spending or public sector size. For example, Agell et al. (1997) claimed that theoretical and empirical evidence does not allow any conclusion on whether there is a relationship between the rate of economic growth and the size of the public sector. In view of their econometric finding, Stefan and Magnus (1999) argued that Agell et al. base their conclusion on empirical studies, and on their own regressions, without evaluating the econometric problems that arise. They extended Agell et al.'s review in order to highlight some of these problems and presented evidence showing that once a number of econometric issues are dealt with, the relationship between growth and public expenditure may be more robustly negative than it first appears.

A closely related field sees much more abundant literature: the economic impact of labor market institutions on employment. The empirical studies in this field also yield mixed results and unresolved debate, particularly since the publication of IMF's report (2003), which used an empirical model of labor market institutions on unemployment to conclude 
that rigid labor market institutions in welfare state induce higher unemployment. The OECD Employment Outlook (2006) presented a similar econometric analysis of regressions of unemployment rate on the labor market institutions variables (average replacement rate, tax wedge, union density, employment protection index, benefit duration and labor tax rate) and provided similar conclusion as that of IMF (2003). This study also referenced other studies with findings that the level and duration of unemployment benefits have a detrimental impact on unemployment (Scarpetta, 1996; Nickell, 1998; Elmeskov et al., 1998; Nunziata, 2002) and empirical studies with findings that high labour taxes tend to increase unemployment rates (Belot and van Ours, 2004; Nickell, 1997) despite other less conclusive studies (Scarpetta, 1996; Nunziata, 2002; Di Tella and MacCulloch, 2005).

However, other researchers argued that the positive correlation between rigidity of labor market institutions and unemployment is not robust to changes of specification or data, see for example Baker, Glyn, Howell, and Schmitt (2002, 2004). They think this conventional view is intuitive thus too simple to represent the complexity of reality and cross-national evidence is weak and fragile. As James Heckman (2007) commented, they did not prove that institutions do not cause the pattern of European unemployment. Instead, they showed that the current data base and models are too weak to decide the issue. The differences in conclusions of these studies may be traced back to different econometric processing methods applied to the same (or similar) original OECD panel data.

Because the key variable of interest in this paper is public social expenditure and four major components of this total welfare spending: income support, pension benefits, public health and other social services, which are quite different from labor institution variables mentioned above, I do not want to go into details on the econometric problems in BGHS's critical work. One point which is striking and worthy of mentioning is their inadequate attention to the problems of reverse causality and omitted variable bias. Both sides of the debate did not address properly the potential endogeniety problem from these two sources. That is the main motivation of my using Durbin-Wu-Hausman endogeneity test before constructing final model in this paper. 
As mentioned before, despite heated debate on economic impacts and performance of welfare states, rigorous econometric studies on the relationship between structural unemployment and social welfare expenditure in developed countries are limited in both quantity and quality. Particularly, no previous study specifically addressed potential endogeneity problem in panel data regressions, so we do not know if the estimates of the variables of interest are unbiased or consistent due to omitted variable bias or reverse causality. What is more important is no previous study explored in depth to reveal the mechanism (or channel) through which welfare expenditure affects employment.

This paper aims to fill this blank by using two-way fixed effect (FE) estimation for panel data of all OECD nations using the latest data from official sources (see table 1), with instrument variable used for endogeneity test and a set of robustness checks subject to the model. The response variables of these FE regressions include unemployment, long-term unemployment rate, youth unemployment rate and investment rate, the last of which is used to test the hypothesis that welfare spending impacts employment through the channel of investment rate.

The paper contributes to the empirical literature on the effects of welfare state on unemployment in three respects. First, it analyzed the impacts of welfare expenditure by government at both sub-component level and aggregate level for the first time, i.e., it examines the four major components of welfare spending (income support, expenditures on pension, public health and other public social services) and total welfare spending separately. The public social welfare expenditure is a composite concept thus some part of this transfer payment system (such as public welfare expenditure on education) is likely to have positive impact while other components may have negative effects. The separate and overall effects of the four components of total welfare spending are investigated. Both the level and structure indicators of unemployment are used, the latter of which refers to long-term unemployment rate representing duration structure and youth unemployment rate representing age structure. Second, for the first time, possible endogeneity and reverse causality from unemployment to welfare spending are formally tested and if endogeneity is found, IV estimation for panel data is used to correct for OLS bias. Third, for the first time, the paper explores the channel through which welfare spending impacts unemployment, specifically the effects on investment rate. 
The rest of the paper is organized as follows: in Section III we discuss the four welfare variables, the data and other variables used in our estimations. Section IV presents the process of the model building, including two econometric tests for model specification. Section V describes the results. Section VI conducts a set of robustness tests and sensitivity analysis. Finally, Section VII summarizes the main findings and discusses some potential policy implications.

\section{THE WELFARE AND THE DATA}

The "welfare" in the concept of welfare state used in this paper refers to public social spending, which measures the amount of resources committed by the government in the areas of pensions, benefits (social support) and health. A traditional argument for much social spending is to prevent disadvantage and thus enhance equity.

This study is based on a panel model of all 34 OECD member states: The OECD Social Expenditure Database. Social expenditure is classified as public when general government (i.e. central administration, local governments and social security institutions) controls the financial flows. For example, sickness benefits financed by compulsory contributions from employers and employees to social insurance funds are considered "public", whereas sickness benefits paid directly by employers to their employees are classified as "private".

According to this data, public social expenditure averaged 19\% of GDP across 34 OECD countries in 2007. Country differences in spending levels were wide. Mexico and Korea spent between 6 and 10\% of GDP. France and Sweden spent about 20 percentage points more. Public spending is a feature of the continental European countries. Between 1982 and 2007, this ratio has risen by 2.5 percentage points on average across OECD countries.

According to OECD (2011), countries with a more equal income distribution, as measured by the Gini coefficient, tended to have higher social spending, however, bigger rises in social spending experienced over the last generation in some countries do not appear to have contributed to reductions in income inequality. 
As for the composition of welfare expenditure, the largest category of public social spending concerns old-age and survivor pensions: on average across the OECD, amounting to almost 7\% of GDP. On average across the OECD, income transfers to the working-age population amounted to almost 5\% of GDP, and within the latter category, public spending targeted to families with children and to persons on unemployment benefits each represented nearly $1.3 \%$ of GDP. On average public expenditure on health services amounted to $6 \%$ of GDP in 2003 while spending on other social services was about $2 \%$ of GDP.

The variables used in this paper, data source and time coverage of each variable are presented in table 1. Four variables are used to represent welfare state: public social welfare expenditure as a percentage of GDP (public_social) and four components of it: 1) income support to households which do not have sufficient other resources to support themselves (income_support), 2) pension expenditure to the old-age and survivor (pension_exp), 3) public expenditure on health services (health_exp) and 4) spending on other social services (otherwelf). All the welfare measures are in percentage of GDP.

Welfare expenditure rate is a better measure for welfare state than government consumption as percentage of GDP because government purchases of goods and services for citizens financed by tax may have significant externality benefits (for example, through education and $R \& D$ ) while welfare spending is more relevant to transfer payment part of government spending, which is more likely to affect individual's incentive to work or individual firm's incentive to make investment. Therefore welfare spending rate is a better measure for non-productive effect of government intervention in economy, which is the interest of this paper. Government expenditure rate, however is a more general measure of the scale of welfare state or entitlement society, which represents the overall net impact of government intervention in economy and will be examined in the section of robustness check and sensitivity analysis.

The main data source of welfare expenditure and its components, OECD Social Expenditure database covers the years 1980 - 2010. Over this period, public social expenditure as a percentage of GDP, on average across OECD, increased from $15.6 \%$ to $19.2 \%$. Public pension spending (6.4\% of GDP) and public health expenditure $(5.8 \%$ of 
GDP) are the largest social spending items (Adema et. al. (2001)). The data of welfare variables between 2008 and 2012 are projected by OECD.

Table 1 presents descriptive statistics of the variables used in the paper. Table 2 presents the correlation between unemployment outcomes and the welfare spending indicators. The correlation between unemployment outcomes and welfare expenditure indicators is in most of the cases positive and statistically significant. The only two exceptions are statistically non-significant correlations between spending rate of public health welfare and youth unemployment rate and between spending rate of other public social services and total unemployment rate. Since the spending rate of other social services is a composite indicator including various welfare programs, this may implies that some of them are likely to have positive impact on unemployment while others have negative effects, the overall effect is neutral.

\section{THE MODEL BUILDING}

The specification of the baseline model used in this paper is:

$$
y_{i t}=\theta_{t}+x_{i t} \gamma+w_{i t} \delta+c_{i}+u_{i t} \quad \mathrm{t}=1,2, \ldots, \mathrm{T}
$$

where $y_{i t}$ is the unemployment rate (total, youth, or long-term unemployment) for country $\mathrm{i}$ at time t. $x_{i t}$ is $1 \times 6$ vector and contains 6 observable explanatory variables which are assumed to be strictly exogenous, including labor productivity growth rate (labor_prodg), terms of trade shock (dtot), inflation rate (inflation), long real interest rate (long_real_r), international trade openness (trade_open) and population density (popd). $w_{i t}$ is the key variable of interest: one of five welfare measures (public_social,

pension_exp, health_exp, income_support and otherwelf), which may be endogenous. ${ }^{c_{i}}$ represent country fixed effects that capture unobserved country-specific determinants of unemployment, which may include some variables with high time constancy, such as national cultural attitude(tradition) towards trade-off between work and leisure or national cultural attitude towards importance of equality of result or equality of opportunity. $\theta_{t}$ is a fixed effect term for aggregate time, which captures global trend of some growth determinants that are common to all OECD countries, such as worldwide 
technology progress or global economic downturns or booms. $u_{i t}$ are idiosyncratic errors, which also absorb some time-varying omitted variables, such as home ownership (as pointed out by OECD (2006, p218), Home ownership is correlated with unemployment). This is a two-way fixed effect model for unbalanced panel data. The reason to choose fixed effect (FE) model rather than random effect (RE) model is for controlling unobservable time-invariant country heterogeneity and global time trend of technology despite the fact that RE estimator may have higher efficiency than FE estimator when unobservables are not correlated with included explanatory variables. The choice of first four control variables (labor_prodg, dtot, inflation, long_real_r) closely follows IMF (2003) and OECD (2006). The inclusion of trade openness and population density as control variables for unemployment rates follows Bernal-Verdugo et. al.(2012). Felbermayr et. al. (2009) also find that higher trade openness is causally associated to a lower structural rate of unemployment.

The implementation of this two-way FE model is the classical approach of Least Squares Dummy Variable Regression (LSDV): adding two sets of dummy variables for country and year, respectively to the OLS regression of (1).

\section{IV.I Test Endogeneity of Welfare Variables}

It is likely that changes in unemployment or economic growth induce changes in welfare spending. Higher unemployment is always accompanied by lower GDP growth, which is translated to lower tax income for government, which in turn may decrease welfare expenditure due to more scarce resources for re-allocation. Beraldo et. al. (2009) point out that a well documented stylized fact is that (total) expenditure in health rises with per capita GDP. On the other hand, opposite effect may arise through another channel: higher unemployment and lower growth indicate bad economy, fewer job opportunities and lower income for working people, so it may be an incentive for dependence on welfare benefits, particularly unemployment benefits. In short, there may exist reverse causality or feedback effect from unemployment rate to welfare expenditure, which violates strict exogeneity assumption for the welfare indicators for OLS estimation. If this assumption fails, the consistency of FE estimates on welfare variables is questionable. The Omitted 
variables, whose data is unavailable or unobservable to us, may also be the source of endogeneity, as discussed before.

I apply classical Durbin-Wu-Hausman (DWH) test to check whether welfare spending is endogenous in our regressions for unemployment rates thus whether IV estimation is necessary. Davidson and MacKinnon (1993) suggest an augmented regression test, which can easily be formed by including the residuals of each endogenous right-hand side variable, as a function of all exogenous variables and instrument variable(s), in a regression of the original model. The key requirement for this approach is that we can correctly identify all other strictly exogenous variables except suspicious endogenous variable(s) and we can find a valid IV. We assume that all explanatory variables in $x_{i t}$ of (1) are strictly exogenous and we suspect that welfare measure in $w_{i t}$ may be endogenous. The IV has to be strongly correlated to $w_{i t}$ but has no direct impact on $\mathrm{y}$ (is uncorrelated with the unobservable error $u_{i t}$ ).

The choice of IV is the trickiest part of DWH test or IV regression. Beraldo et. al. used lagged values (up to three period) of possibly endogenous variables (health spending variables). These IVs are of course strongly correlated with endogenous variables but the exogeneity of them is highly suspicious. Using lagged values of possibly endogenous variables as instruments is never an appropriate way to ensure strictly exogeneity of the instruments for panel data. As Angrist \& Krueger (2001) pointed out, "One of the most mechanical and naive, yet common, approaches to the choice of instruments uses atheoretical and hard-to-assess assumptions about dynamic relationships to construct instruments from lagged variables in time series or panel data. The use of lagged endogenous variables...is problematic if the equation error or omitted variables are serially correlated". It is easy to verify that unemployment rate regressions always have residual errors serially correlated. So Beraldo et.al. (2009)'s approach of using one to three period lagged values of endogenous variable (health spending expenditure) as instrument variables makes the exogeneity of these IVs very questionable.

The instrument variable (IV) chosen for welfare variables in this paper is road fatalities per million inhabitants (road) whose data comes from OECD Factbook 2010. Road fatality means any person killed immediately or dying within 30 days as a result of a road 
injury accident. Suicides involving the use of a road motor vehicle are excluded. The justification of the validity of this IV is elaborated as follows.

Death rate from road accidents presumably cannot affect unemployment and seems to have nothing to do with the omitted variables that affect unemployment rate, such as home ownership. However, this rate may be related to welfare spending rate in this way: in welfare states with higher welfare expenditure by government and more generous welfare benefit programs, people tend to have more leisure time and slower life pace. To prove this, a simple fixed effect model of hours on each welfare variable is run where hours, as defined before, is average hours actually worked per year per person in employment. The first five rows of table 4 clearly show that average annual hours actually worked per worker in OECD nations have strong negative association with total welfare spending rate and its four components. The estimate of public_social indicates that on average, in an OECD country, one percentage increase in welfare spending rate leads to a reduction of working hours by about five hours in one year. Interestingly, Welfare spending on other social services as percentage of GDP (otherwelf) has significant positive effect on working hours. This may imply that although three biggest parts of welfare expenditure and total welfare spending provide disincentive to working, overall, welfare spending on other public social services provide incentive to working. Different patterns of time allocation between working and leisure lead to different life paces. The life pace is presumably closely related to the probability of traffic accidents. As the second step of the test on my hypothesis of the relationship between road fatality rate and welfare level, a simple fixed effect model of road fatality rate on hours is run, the estimate shown in table 4 is 0.0576 , indicating that on average, one more extra working hour increases the road fatality rate (per million people) by about 0.06 . Consequently, when a simple FE regression of road fatality on total welfare spending rate is run, welfare expenditure has a strongly significant estimate -2.01 , implying that one percentage point increase in welfare spending relative to GDP is translated into a drop of road fatality incidence by 2.01 (per million inhabitants). As the table 2 shows, similar relationships can be found for other welfare variables (income_support, pension_exp, health_exp) but not for otherwelf. 
Because road has no significant correlation with otherwelf, another instrument variable has to be found for this welfare measure. I choose proportion of seats held by women in national parliaments (women) to instrument spending rate of other social services. The justification of this IV is the ratio of welfare expenditure on various public social services to GDP is presumably related to the importance an average voter of a nation attaches to wealth equality or income equality. A country emphasizing income equality presumably also stresses on other aspect of equality, such as gender equality. In this sense, the variable women measuring gender equality can also represent national attitude towards other forms of equality, such as economic equality, which directly affects welfare expenditure.

The overall IV relevance test is performed by running a Least Squares Dummy Variable Regression (LSDV) of a welfare variable on the IV (road or women) and six exogenous control variables, i.e., all variables in $x_{i t}$ of (1). The table 5 indicates that the IV road is a strong IV for income-support, pension_exp and public_social according to Sotck and Yogo (2005)'s thumb rule of F value exceeding 10 for one endogenous variable. It is a very weak IV for health_exp (F statistic $3.59 \mathrm{p}$ value 0.0589 ). The IV women is also relatively weak for otherwelf although the F statistic is 8. Since health_exp has no valid instrument, it is assumed to be exogenous and will not be subject to endogeneity (DWH) test.

The Durbin-Wu-Hausman (DWH) test can be performed as follows: we first regress a welfare measure on all the explanatory variables in $x_{i t}$ of (1) (long_real_r, labor_prodg, trade_open, popd, inflation and dtot ), an instrument variable for welfare (road /women), dummy variables for each country and dummy variables for each year and obtain the residual, $\hat{v}_{2}$. Then we simply include $\hat{v}_{2}$ along with unity, all the variables in $x_{i t}$ and $w_{i t}$ of (1) and dummy variables for nations and years in an OLS regression of one unemployment indicator (unemp/long_unem2/youth_unem2) and obtain the $t$ statistic on $\hat{v}_{2}$. The $\mathrm{p}$ values for the estimated parameters of $\hat{v}_{2}$ for all welfare measures but health_exp are presented in table 5. We can only find evidence of endogeneity for income_support for total unemployment rate (unemp) at 5 percent significance level against a two-sided alternative, so 2SLS estimation is only necessary for income_support 
in the regression for unemp to ensure consistency of the estimate of income_support. The DWH statistic of public_social is also marginally significant at $10 \%$ level (p value $=0.0824$ ) for unemp. Since this $p$ value indicates a very weak endogeneity, both IV and OLS regressions will be run and results will be compared. A LSDV approach will be adopted for estimation of the final models for three unemployment rates. Among the regressions, that with dependent variable unemp and independent variable income_support will be a 2SLS regression with an IV road.

\section{IV.II Test Persistence of Unemployment Rate: a Dynamic Version of the Baseline Model}

As Bernal-Verdugo et. al. point out, it is important to note there is high persistence of unemployment rates. According to their estimation results, a one percentage point increase in previous unemployment translates into a 0.83 percentage point higher unemployment in the current period, which can be dubbed as a "momentum" effect of pre-existing unemployment rate levels. OECD (2006) also indicates that a macroeconomic shock might not only raise current unemployment but, in addition, its effects might persist over time. In order to assess initial versus persistence effects of shocks, a dynamic version of the baseline model (1) is needed.

Generally, for a dynamic FE model:

$y_{i t}=z_{i t} \gamma+\rho_{1} y_{i, t-1}+c_{i}+u_{i t}$

To test persistence (state dependence), first-differencing equation (2) gives:

$\Delta y_{i t}=\Delta z_{i t} \gamma+\rho_{1} \Delta y_{i, t-1}+\Delta u_{i t}$

Following Wooldrige (2001, pp. 299), to test for state dependence in total unemployment rate, after allowing for unobserved country effects, the model is applying an IV regression to equation (3) with $y_{i t}$ being unemp but without any other explanatory variables $\Delta z_{i t}$, where $y_{i, t-2}, y_{i, t-3}$ are used to instrument $\Delta y_{i, t-1}$. Further, to correct for possible serial correlation in $\Delta u_{i t}$, I use standard error robust to arbitrary form of heteroskedasticity or serial correlation (Wooldrige (2001, p275). 
The $\mathrm{F}$ statistic for joint significance of $y_{i, t-2}, y_{i, t-3}$ in the first stage regression for $\Delta y_{i, t-1}$ yields $\mathrm{p}$-value of 0 , indicating they are strong instruments. The 2 SLS estimation of the first-differenced equation (3) without $\Delta z_{i t}$ gives an estimate of the coefficient of $\Delta y_{i, t-1}$ of 0.3358 , which has a robust standard error 0.064 and $\mathrm{p}$ value 0 , indicating that overall, there is strong state dependence for unemp, similar results are found for long unemployment rate and youth unemployment rate. Therefore we do need to put the lag of response variable of unemployment rate as a regressor and to extend the econometric model to dynamic specification for our data as shown below.

$y_{i t}=y_{i t-1}+\theta_{t}+x_{i t} \gamma+w_{i t} \delta+c_{i}+u_{i t} \quad \mathrm{t}=1,2, \ldots, \mathrm{T}$

Consequently, the estimation method will change from pure LSDV to LSDV+IV with IV being two-period and three-period lagged values of the response variable (for the regression of unemp on income_support, additional IV of road is needed).

\section{THE RESULTS}

The main results regarding the relationship between unemployment and welfare measures are shown in Table 6- table 8, which display the estimates for the dynamic specification of the econometric model (4). First and foremost, it should be noted that, in the regressions for all three unemployment rates, we find that three welfare measures have a statistically significant positive effect: spending rates of income support, pension benefit and total welfare. Specifically, increasing the total welfare spending rate (public_social) by one standard deviation increases, on average, the total unemployment rate by about 1.06 percentage points $\left(0.1675^{*} 6.3510\right)$. Interestingly, for all three unemployment rates, the estimates of income_support and pension_exp both have higher magnitudes than that of public_social. In other words, the magnitudes of the estimates of two sub-components of total welfare spending are larger than that of total welfare expenditure. This implies that some other sub-components of total welfare spending, which are captured by otherwelf or health_exp may have negative effects on unemployment, which in turn offset part of the impacts from income support and pension expenditure on unemployment. So the net impact of these negative effects from unidentified subcomponents of total welfare spending (for example welfare on public education) and 
positive effects from income support and pension is statistically and significantly positive but has a lower magnitude than that of either income support or pension. For total unemployment rate, since public health expenditure has a marginally significant estimate (which is in conflict with Beraldo et. al.(2009)'s finding that public health expenditure has significantly positive effect on economic growth), it can be sure that negative effects come from other social services, which have only quantitative impacts but not qualitative impacts on unemployment rate. In other words, some sub-components in other social welfare services can only affect the magnitude of the estimate of total welfare spending rate but not the direction. Overall, one percentage point increase in the spending rate of total welfare is associated with a 0.17 percentage point increase in the unemployment rate.

The DWH test result for total welfare spending rate (public_social) in table 4 indicates that the DWH statistic has a $\mathrm{p}$ value of 0.0824 . If we take significance level at $5 \%$, it is exogenous, if $10 \%$ endogenous. The last column in table 5 also shows the IV estimate of public_social when it is taken as an endogenous variable and road is used as an IV (in addition to two lagged values of unemployment rate as IVs). The estimate's magnitude becomes much larger but has the same sign in this case.

We then turn to the result for the next unemployment measure: long-term unemployment rate, which is the proportion of people who have been unemployed for 12 months or more among all unemployed. It is a measure that can better represent the impacts of institutions and policies other than cyclical shock on unemployment as it has less influence from short-term fluctuation of aggregate demand. As OECD Factbook 2011 points out, "Longterm unemployment is of particular concern to the people affected and to policy makers. Quite apart from the mental stress caused to the unemployed and their families, high rates of long-term unemployment indicate that labour markets are operating inefficiently. In countries that pay generous unemployment benefits, the existence of long-term unemployment is also a significant burden on government finances". The standard total unemployment rate measures short-term fluctuation of unemployment level while longterm unemployment rate reflects duration structure of unemployment.

The impact of welfare expenditure on long-term unemployment rate shows similar regularity as that for standard total unemployment rate. One standard deviation increase 
in total welfare spending rate increases long unemployment rate by 3.895 $\left(0.6133^{*} 6.3510\right)$ percentage points. The impacts from income support and pension expenditure are even higher, ranging from 6.09 to 11.29 percentage points for one standard deviation increase. These substantial effects demonstrate that the impact of welfare state on unemployment is not only caused by business cycle shock, it is a structural problem with fundamental institutional and policy causes. No matter how supporters of welfare state claim that entitlement society is neutral to economic performance, the real data clearly shows that the scale of welfare programs is positively correlated with unemployment, in both short and long terms, in both level and in duration structure.

The results for youth unemployment rate in table 8 further reinforce the above conclusion. Every percentage point increase in total welfare spending rate is associated with 0.25 percentage point increase in youth unemployment rate. Equivalently, one standard deviation increase in total welfare spending rate increases youth unemployment rate by $4.789(0.2469 * 6.3510)$ percentage points. The youth unemployment rate is unemployed youth as percentage of youth labor force between 15 and 24 year old. It represents age structure of unemployment. This estimate $(0.2469)$ is higher than that for total unemployment rate $(0.1675)$, suggesting that policy effect of welfare programs is higher for young people than for adults workers.

Among the control variables, we find that trade openness has significant negative effects and population density has positive effects on total unemployment rate and youth unemployment rate. The former conforms to the findings of Bernal-Verdugo et. al.(2012) and Felbermayr et. al. (2009). The latter is consistent with intuition. It is interesting to compare two neighboring countries with striking difference in population density: Canada and USA. During the three decades between 1980 and 2010, the average population density is 3.22 and 29.12 for Canada and US respectively. If everything else were equal, the average unemployment rate of the US during this period should be much higher than that of Canada based on our significant estimates of popd. However, the fact is the real average unemployment of US during this period is $6.3 \%$ while that of Canada is $8.6 \%$. Of course there are many reasons for this difference. According to our estimation results in table 6 , welfare spending rate plays an important role. The real data 
supports our derivation: the average total welfare spending rate during this period is $17.5 \%$ and $14.97 \%$ for Canada and USA respectively. If the United States takes on the road of European welfare states, the US unemployment rate would definitely rise, so does long-term unemployment rate and youth unemployment.

To further explore the mechanism of the effect of welfare spending, a hypothesis is proposed that one mechanism through which welfare spending impacts on unemployment is decreasing investment because tax on the income from capital reduces the incentive to save for businesses. Investment rate is vital to growth and employment. The results in table 9 test and validate this hypothesis. The control variables include inflation, long real interest rate and trade openness. The FE estimates for five welfare measures give strong evidence to support the hypothesis: one percentage increase in total welfare spending rate is associated with about 0.29 percentage point decrease in investment rate. Similar to the effects on unemployment rate, only income support, health expenditure and total welfare spending have significant impacts. The fact that the estimate of the last is higher than the former two variables implies that some other components of public social expenditure may have positive effects on investment that counteract the impact of pension and income support to some extent. Through the negative effect on investment, welfare spending can affect both employment and economic growth. The latter effect is supported by Ding (2012)'s econometric study.

\section{THE ROBUSTNESS CHECK AND SENSITIVITY ANALYSIS}

To check the robustness of our estimation results to specification change, I re-run the model (4) with two control variables changed and one control variable added: labor productivity growth replaced by multi factor productivity growth rate and terms of trade shock by the lagged value of terms of trade change. The added control variable is net migration rate, which is defined as the difference between immigration into and emigration from the country during the year per 1000 inhabitants.

The motivation of adding this explanatory variable is derived from the significant estimates of pension spending rate (pension_exp) shown in table 6. Since pension benefit expenditure is shown to be one of two parts of welfare spending that hinder employment, 
the immediate employment-promoting policy implication is either lowering social security tax rate or raising full retirement age (equivalently, increasing the contribution period needed to qualify for full pensions) or reducing proportion of retirees in the population. Lowering social security tax implies benefit cut, which inevitably will encounter fierce resistance from senior voters. Raising retirement age is also unpopular. As shown before, people in generous welfare states tend to work less time due to disincentive effect of welfare benefits (see the first panel of table 4). Increasing lifetime working time by raising social security eligibility age will also be most likely to bring about strong political opposition. The most hopeful solution then goes to the last option: reducing proportion of retirees in the population by introducing more working-age immigrants. Admitting working-age immigrants, particularly those with high skills is hypothesized to be able to deter the trend of ageing of population, to decrease pension benefit expenditure as a percentage of GDP and thus to facilitate economic growth and employment.

This hypothesis is tested by adding net migration rate (migrate) to model (4) with the above-mentioned changed and added control variables. The results corresponding to table 6 are presented in table 10 (DWH test shows that income_support is not endogenous in this specification).

The estimates for the welfare variables are quite close to those in table 6 except that of income_support. Because of not using IV road, the estimate of income_support has higher efficiency and lower magnitude but no qualitative change. As in the case of table 6 , the significant estimates of income_support and pension_exp have higher magnitudes than that of public_social. The estimates of migrate are strongly significant in all cases. One percentage point increase in net migration rate translates into 0.09 percentage point increase in total unemployment rate. Equivalently, one standard deviation increase in net migration rate yields a $0.4(0.0899 * 4.4158)$ percentage point increase in unemployment rate, supporting our hypothesis on the impact of immigration on unemployment. This econometric test refutes the claim widely seen in press that immigrants snatch job opportunity from native workers. The data tells us the opposite thing: immigrants are decreasing unemployment rate by contributing to pension system and bringing in talents and technology. This finding is consistent with Muysken and Ziesemer (2011)'s 
conclusion that immigration can help to alleviate the burden ageing presents for the welfare states of most Western Economies.

As the final robustness check for the economic impact of welfare state, a more general measure for welfare state or entitlement society is used to replace welfare measures, that is, the total government expenditure as a percentage of GDP (govexp), which indicates the size of government and reflects historical and current political decisions about its role in providing services and in redistributing income. Government expenditure, which includes welfare expenditure, of course contains some items that have positive externality and thus are productive investment that promote growth and employment, as mentioned in section III, but what is the overall net effect of various sub-components of government expenditure? The last column of table 10 gives us an answer: The estimate of govexp indicates that every percentage point increase in total government expenditure as a share of GDP can increase total unemployment rate by 0.37 percentage point. This strongly significant estimate is consistent with that of total welfare spending rate and also consistent with Tullio (1987)'s finding that "the tax-financed growth in government expenditure which has occurred in the last 20-25 years has caused unemployment and slowed down the rate of economic growth during the period." and Grier and Tullock (1989)'s finding that the growth of government consumption is significantly negatively correlated with the economic growth. The estimates of welfare expenditure rate and government spending rate undoubtedly have profound policy implication for the decision makers in Western Economies, particularly in face of European Sovereign Debt Crisis and American Deficit Crisis.

\section{CONCLUSION}

This paper contributes to the empirical literature on the economic effect of welfare state in three respects. First, while almost all of previous studies have mostly focused on public expenditures in health and education or total welfare spending on GDP growth rate, this paper focus the impacts of four biggest components of welfare expenditure on three unemployment measures: total unemployment rate, long-term unemployment rate and youth unemployment rate. Second, this paper formally tests potential endogeneity of the variable of interest: welfare variable by using Durbin-Wu-Hausman test to ensure 
estimation unbiasedness and consistency. Third, this paper identifies two sources of negative effect of welfare spending: income support and pension benefit. So the effect of welfare state or entitlement society is analyzed at both sub-component and aggregate level. Third, this paper econometrically tests the hypothesis that one channel through which welfare spending impacts employment is investment rate.

The findings in this paper indicate that, after controlling for other macroeconomic and demographic variables, an increase in the total welfare spending rate (relative to GDP) has a statistically significant positive impact on unemployment outcomes (i.e., total, youth, and long-term unemployment). Among the four components of total welfare expenditure analyzed, only income support and pension benefit are found to have significant effect on all unemployment outcomes (public expenditure on health services has marginally significant positive effect on total unemployment rate, but not on longterm unemployment rate and youth unemployment rate) and their impacts have larger magnitudes than that of total welfare spending, implying that some unidentified subcomponents in other public social services (probably welfare expenditure on public education) have negative impacts on unemployment, which offset the impacts from income support and pension expenditure to some extent.

Besides the finding that entitlement society with high welfare expenditure necessarily accompanies high unemployment, the econometric estimation results of the paper also provide evidence to support the hypothesis that one channel through which welfare expenditure impacts unemployment is investment rate. Through the negative effect on investment, welfare spending can affect both employment and economic growth.

The finding also suggests that contrary to the claim widely seen in press that immigrants snatch job opportunity from native workers, immigration can decrease a nation's unemployment rate. Combining this with the finding that total government expenditure as a share of GDP has a significantly positive impact on unemployment rate, as total welfare spending rate does, Overall the results of this paper suggest that policies that cut welfare expenditures on income support and pension benefits should reduce unemployment. Another way of facilitating employment is introducing more working-age immigrants, particularly skillful immigrants, which is a feasible way to deter population ageing and soaring pension spending rate and decreasing unemployment rate. 
Table 1 The variable definitions, data sources and time coverage of data

\begin{tabular}{|c|c|c|c|}
\hline variable & Definition & Data source & Time coverage \\
\hline dtot & $\begin{array}{l}\text { Percentage change in the terms of trade weighted by the } \\
\text { trade openness of the country }\end{array}$ & WDI2010 & $1981-2010$ \\
\hline govexp & Government expenditure as \% of GDP & & $1960-2010$ \\
\hline health_exp & Public social expenditures on Health as a percentage of GDP & SOCX & $1980-2007$ \\
\hline hours & $\begin{array}{l}\text { Average hours actually worked: } \\
\text { Hours per year per person in employment }\end{array}$ & OECD Factbook 2010 & $1980-2012$ \\
\hline income_support & $\begin{array}{l}\text { Public social expenditures on income support to the working- } \\
\text { age population as } \% \text { GDP }\end{array}$ & SOCX & $1955-2010$ \\
\hline inflation & $\begin{array}{l}\text { Inflation rate: Consumer price indices (CPI): annual growth in } \\
\text { percentage }\end{array}$ & OECD Factbook 2010 & $1955-2008$ \\
\hline invrate & $\begin{array}{l}\text { Investment rate: the share of total GDP that is devoted to } \\
\text { investment in fixed assets }\end{array}$ & OECD Factbook 2010 & $1976-2006$ \\
\hline $\begin{array}{l}\text { Labor_prodg } \\
\text { Long_real_r }\end{array}$ & $\begin{array}{l}\text { Labor productivity growth rate } \\
\text { long real interest rate :The nominal returns on long-term } \\
\text { government bond minus the actual inflation rate over the } \\
\text { following year }\end{array}$ & OECD StatExtracts & $1990-2011$ \\
\hline Long_unem2 & $\begin{array}{l}\text { Long unemployment rate: proportion of people who have } \\
\text { been unemployed for } 12 \text { months or more among all } \\
\text { unemployed }\end{array}$ & WDI2010 & $1980-2010$ \\
\hline mf_prodg & Multi-factor Productivity growth & OECD StatExtract & $1985-2010$ \\
\hline migrate & $\begin{array}{l}\text { Net migration rate: The difference between immigration into } \\
\text { and emigration from the area during the year per } 1000 \\
\text { inhabitants }\end{array}$ & OECD Factbook 2010 & $1955-2008$ \\
\hline otherwelf & $\begin{array}{l}\text { Welfare spending on other social services as percentage of } \\
\text { GDP }\end{array}$ & socx & $1955-2010$ \\
\hline pension_exp & Public social expenditures on pension as \% GDP & socx & $1980-2010$ \\
\hline popd & Population density (people per square $\mathrm{km}$ of land area) & WDI2010 & $1961-2010$ \\
\hline public_social & Public Social Expenditure as percentage of GDP & socx & $1980-2010$ \\
\hline road & Road fatalities Per million inhabitants & OECD Factbook 2010 & $1990-2008$ \\
\hline Trade_open & International trade openness (\% of GDP) & WDI2010 & $1960-2008$ \\
\hline unemp & Unemployment rate & OECD Factbook & $1955-2010$ \\
\hline women & $\begin{array}{l}\text { Proportion of seats held by women in national parliaments } \\
\text { (\%) }\end{array}$ & WDI2010 & $1990-2011$ \\
\hline Youth_unem2 & Youth unemployment rate: \% of youth labour force (15-24) & WDI2010 & $1980-2010$ \\
\hline
\end{tabular}

Note: WDI2010: World Development Indicator 2010 Edition, World Bank. SOCX: The OECD Social Expenditure Database 
Table 2 Summary Statistics for variables used in the models

\begin{tabular}{|c|c|c|c|c|c|}
\hline Variable & $\mathrm{N}$ & Mean & Std Dev & Minimum & Maximum \\
\hline unemp & 989 & 6.5237 & 3.7334 & 0.1 & 20.1494 \\
\hline long_unem2 & 817 & 32.4050 & 17.8792 & 0.3 & 76.2000 \\
\hline youth_unem2 & 889 & 15.5267 & 8.2267 & 2.6 & 43.9 \\
\hline income_support & 971 & 4.6195 & 2.4429 & 0 & 13.4 \\
\hline pension_exp & 954 & 6.8259 & 3.0288 & 0.2 & 14.1 \\
\hline health_exp & 967 & 5.3930 & 1.4556 & 0.7 & 9.4 \\
\hline otherwelf & 923 & 2.5674 & 1.9509 & 0 & 10.3 \\
\hline public_social & 951 & 19.3968 & 6.3510 & 1.7 & 35.7 \\
\hline labor_prodg & 694 & 1.9347 & 2.4922 & -11.6 & 17.5 \\
\hline mf_prodg & 456 & 1.2140 & 1.7142 & -7.6 & 7.6 \\
\hline dtot & 688 & 0.0198 & 1.8160 & -10.2448 & 22.5451 \\
\hline inflation & 1513 & 12.1580 & 47.3427 & -3.5 & 1281.4 \\
\hline trade_open & 1187 & 34.8219 & 21.5213 & 4 & 160.5 \\
\hline popd & 1622 & 115.4203 & 113.2750 & 1.3646 & 508.8568 \\
\hline invrate & 1193 & 22.8427 & 4.1450 & 14.8 & 37.5 \\
\hline migrate & 1512 & 1.6707 & 4.4158 & -23.1 & 40.3 \\
\hline road & 637 & 115.2418 & 46.6745 & 37 & 316 \\
\hline
\end{tabular}

Table 3 Correlation Matrix of Unemployment Rates and Welfare Measures

\begin{tabular}{|c|c|c|c|c|c|c|c|c|}
\hline & unemp & long_unem2 & youth_unem2 & income & pension & health & otherwelf & welfare \\
\hline unemp & 1 & & & & & & & \\
\hline long_unem2 & $0.5777^{* * *}$ & 1 & & & & & & \\
\hline youth_unem2 & $0.8824^{* * *}$ & $0.5782^{* * *}$ & 1 & & & & & \\
\hline income & $0.1821^{* * *}$ & $0.1830 * * *$ & $0.0910 * * *$ & 1 & & & & \\
\hline pension & $0.3217^{* * *}$ & $0.5505^{* * *}$ & $0.4131^{* * *}$ & $0.2514^{* * *}$ & 1 & & & \\
\hline health & $0.0657^{*}$ & $0.1006^{* * *}$ & 0.0033 & $0.4109 * * *$ & $0.5179 * * *$ & 1 & & \\
\hline otherwelf & -0.0433 & $-0.2491^{* * *}$ & $-0.1112^{* * *}$ & $0.5205^{* * *}$ & -0.0161 & $0.4019 * * *$ & 1 & \\
\hline welfare & $0.2259 * * *$ & $0.2911^{* * *}$ & $0.1933^{* * *}$ & $0.7681 * * *$ & $0.7054 * * *$ & $0.7739 * * *$ & $0.6097 * * *$ & 1 \\
\hline
\end{tabular}

Note: income=income_support; pension=pension_exp; health=health_exp; welfare=public_social.

$*,{ }^{*},{ }^{*} * *$ denote significance at 10 percent, 5 percent, and 1 percent, respectively.

Table 4 The relationships between working hours, road fatality and welfare variables

\begin{tabular}{lllllll}
\hline $\begin{array}{l}\text { Dependent } \\
\text { variable }\end{array}$ & Independent variable & coefficient & \multicolumn{2}{l}{$\begin{array}{l}\text { Standard } \\
\text { Error }\end{array}$} & \multicolumn{2}{l}{$\begin{array}{l}\text { P value for } \\
\text { R-square }\end{array}$} \\
\hline hours & Public_social & -4.4143 & 1.1136 & 0.0000 & 0.96 & 698 \\
& Income_support & -4.0495 & 1.8387 & 0.028 & 0.95 & 710 \\
& Pension_exp & -9.7614 & 2.3246 & 0.000 & 0.96 & 693 \\
& Health_exp & -22.8939 & 3.6359 & 0.000 & 0.95 & 706 \\
& otherwelf & 13.1506 & 4.0490 & 0.0012 & 0.96 & 673 \\
\hline road & hours & 0.0576 & 0.0176 & 0.001 & 0.88 & 574 \\
& Public_social & -2.0141 & 0.4415 & 0.0000 & 0.89 & 564 \\
& Income_support & -2.6313 & 0.8069 & 0.001 & 0.88 & 575 \\
& Pension_exp & -2.8680 & 0.9061 & 0.002 & 0.88 & 564 \\
& Health_exp & -5.3748 & 1.5245 & 0.000 & 0.88 & 572 \\
& otherwelf & -0.3952 & 1.8835 & 0.834 & 0.88 & 546 \\
\hline
\end{tabular}

Note: All the regressions include both time and country fixed effects. 
Table 5 The results of IV strength test \& DWH endogeneity test

\begin{tabular}{|c|c|c|c|c|c|c|}
\hline $\begin{array}{l}\text { Response } \\
\text { variable }\end{array}$ & statistic & Income_support & Pension_exp & Health_exp & Otherwelf & Public_social \\
\hline \multirow[t]{2}{*}{ unemp } & $\begin{array}{l}\text { IV strength F } \\
\text { statistic }\end{array}$ & $9.92(0.0018)$ & $16.73(0.0001)$ & $3.59(0.0589)$ & $8.00(0.0051)$ & $11.16(0.0009)$ \\
\hline & DWH statistic & $3.92(0.0486)^{* *}$ & $0.94(0.3337)$ & & $0.87(0.3530)$ & $3.03(0.0824)^{*}$ \\
\hline $\begin{array}{l}\text { Long_unem } \\
2\end{array}$ & DWH statistic & $2.13(0.1452)$ & $0.22(0.6396)$ & & $0.43(0.5124)$ & $1.43(0.2322)$ \\
\hline $\begin{array}{l}\text { Youth_une } \\
\text { m2 }\end{array}$ & DWH statistic & 1.03 (0.3109) & $0.02(0.8851)$ & & $0.44(0.5095)$ & $0.72(0.3982)$ \\
\hline
\end{tabular}

Note: The IV of otherwelf is women, that of other variables is road.

IV strength test is a regression of one welfare measure on the column header (one of income_support, pension_exp, health_exp, otherwelf and public_social) on long_real_r, labor_prodg, trade_open, popd, inflation and dtot, IV (road /women), dummy variables for each country and dummy variables for each year.

DWH endogeneity test is a regression of one unemployment measure (one of unemp, long unem2, youth unem2) on one welfare measure(one of income_support, pension_exp, health_exp, otherwelf and public_social), long_real_r, labor_prodg, trade_open, popd, inflation, dtot, dummy variables for each country, dummy variables for each year and the residual from the IV strength test.

$*, * *, * * *$ denote significance at 10 percent, 5 percent, and 1 percent, respectively.

Table 6 The results of Final Models for Total Unemployment Rate

\begin{tabular}{|c|c|c|c|c|c|c|}
\hline & unemp & unemp & unemp & unemp & unemp & unemp \\
\hline Income_support & $\begin{array}{l}0.9534 \\
(0.3784)^{* *}\end{array}$ & & & & & \\
\hline Pension_exp & & $\begin{array}{l}0.4429 \\
(0.1078)^{* * *}\end{array}$ & & & & \\
\hline Health_exp & & & $0.3109(0.1794)^{*}$ & & & \\
\hline otherwelf & & & & $\begin{array}{l}0.0038 \\
(0.1902)\end{array}$ & & \\
\hline Public_social & & & & & $\begin{array}{l}0.1675 \\
(0.0459)^{* * *}\end{array}$ & $\begin{array}{l}0.5187 \\
(0.2346)^{* *}\end{array}$ \\
\hline $\begin{array}{l}\text { One year lagged } \\
\text { value of unemp }\end{array}$ & $\begin{array}{l}0.7742 \\
(0.0702)^{* * *}\end{array}$ & $\begin{array}{l}0.7343 \\
(0.0307)^{* * *}\end{array}$ & $\begin{array}{l}0.8030 \\
(0.0250)^{* * *}\end{array}$ & $\begin{array}{l}0.7890 \\
(0.0313)^{* * *}\end{array}$ & $\begin{array}{l}0.7667 \\
(0.0320)^{* * *}\end{array}$ & $\begin{array}{l}0.7283 \\
(0.0754)^{* * *}\end{array}$ \\
\hline Labor_prodg & $0.0011(0.0496)$ & $0.0799(0.0413)^{*}$ & $0.0623(0.0352)^{*}$ & $\begin{array}{l}0.0538 \\
(0.0357)\end{array}$ & $\begin{array}{l}0.0554 \\
(0.0370)\end{array}$ & $\begin{array}{l}0.0579 \\
(0.0476)\end{array}$ \\
\hline dtot & $0.0055(0.0593)$ & $0.0245(0.0276)$ & $0.0102(0.0288)$ & $\begin{array}{l}0.0058 \\
(0.0304)\end{array}$ & $\begin{array}{l}0.0172 \\
(0.0334)\end{array}$ & $\begin{array}{l}0.0415 \\
(0.0565)\end{array}$ \\
\hline inflation & $0.0121(0.0308)$ & $-0.0089(0.0229)$ & $-0.0236(0.0217)$ & $\begin{array}{l}-0.0224 \\
(0.0189)\end{array}$ & $\begin{array}{l}-0.0082 \\
(0.0221)\end{array}$ & $\begin{array}{l}0.0235 \\
(0.0381)\end{array}$ \\
\hline Long_real_r & $0.0270(0.0434)$ & $0.0668(0.0418)$ & $0.0675(0.0401)^{*}$ & $\begin{array}{l}0.0711 \\
(0.0419)^{*}\end{array}$ & $\begin{array}{l}0.0585 \\
(0.0418)\end{array}$ & $\begin{array}{l}0.0308 \\
(0.0465)\end{array}$ \\
\hline Trade_open & $-0.0250(0.0317)$ & $\begin{array}{l}-0.0573 \\
(0.0181)^{* * *}\end{array}$ & $\begin{array}{l}-0.0519 \\
(0.0181)^{* * *}\end{array}$ & $\begin{array}{l}-0.0663 \\
(0.0184)^{* * *}\end{array}$ & $\begin{array}{l}-0.0453 \\
(0.0178)^{* *}\end{array}$ & $\begin{array}{l}-0.0014 \\
(0.0413)\end{array}$ \\
\hline popd & $0.0875(0.0489)^{*}$ & $\begin{array}{l}0.0437 \\
(0.0134)^{* * *}\end{array}$ & $\begin{array}{l}0.0431 \\
(0.0120)^{* * *}\end{array}$ & $\begin{array}{l}0.0434 \\
(0.0166)^{* * *}\end{array}$ & $\begin{array}{l}0.0443 \\
(0.0157)^{* * *}\end{array}$ & $\begin{array}{l}0.0467 \\
(0.0538) \\
\end{array}$ \\
\hline Additional IV & road & & & & & road \\
\hline R square & 0.9589 & 0.9674 & 0.9659 & 0.9649 & 0.9678 & 0.9513 \\
\hline $\mathrm{N}$ & 375 & 375 & 375 & 375 & 375 & 375 \\
\hline
\end{tabular}

Note: Robust clustered standard errors in parenthesis. *,**,*** denote significance at 10 percent, 5 percent, and 1 percent,

respectively. All the regressions are IV regressions with two IVs to instrument the lagged value of response variable: two-year and three-year lagged values of the response variable, additional IV is specified in the table. All the regressions include fixed effects of both year and country. 
Table 7 The results of Final Models for Long Unemployment Rate

\begin{tabular}{|c|c|c|c|c|c|}
\hline & Long_unem2 & Long_unem2 & Long_unem2 & Long_unem2 & Long_unem2 \\
\hline Income_support & $\begin{array}{l}1.3179 \\
(0.4043)^{* * *}\end{array}$ & & & & \\
\hline Pension_exp & & $\begin{array}{l}1.6545 \\
(0.2604)^{* * *}\end{array}$ & & & \\
\hline Health_exp & & & $0.8738(0.6302)$ & & \\
\hline otherwelf & & & & $\begin{array}{l}-0.2256 \\
(0.4736)\end{array}$ & \\
\hline Public_social & & & & & $\begin{array}{l}0.6133 \\
(0.1540)^{* * *}\end{array}$ \\
\hline $\begin{array}{l}\text { One year lagged } \\
\text { value of long_unem2 }\end{array}$ & $\begin{array}{l}0.7320 \\
(0.0573)^{* * *}\end{array}$ & $\begin{array}{l}0.6880 \\
(0.0478)^{* * *}\end{array}$ & $\begin{array}{l}0.7336 \\
(0.0546)^{* * *}\end{array}$ & $\begin{array}{l}0.7259 \\
(0.0521)^{* * *}\end{array}$ & $\begin{array}{l}0.7182 \\
(0.0515)^{* * *}\end{array}$ \\
\hline Labor_prodg & $0.1882(0.1113)^{*}$ & $\begin{array}{l}0.3407 \\
(0.0934)^{* * *}\end{array}$ & $0.2646(0.1064)^{* *}$ & $\begin{array}{l}0.2393 \\
(0.1129)^{* *}\end{array}$ & $\begin{array}{l}0.2562 \\
(0.0997)^{* * *}\end{array}$ \\
\hline dtot & $-0.0325(0.0697)$ & $-0.0262(0.0704)$ & $-0.0763(0.0728)$ & $\begin{array}{l}-0.1086 \\
(0.0763)\end{array}$ & $\begin{array}{l}-0.0095 \\
(0.0722)\end{array}$ \\
\hline inflation & $\begin{array}{l}-0.7067 \\
(0.1607)^{* * *}\end{array}$ & $\begin{array}{l}-0.5793 \\
(0.1501)^{* * *}\end{array}$ & $\begin{array}{l}-0.7283 \\
(0.1579)^{* * *}\end{array}$ & $\begin{array}{l}-0.7299 \\
(0.1589)^{* * *}\end{array}$ & $\begin{array}{l}-0.6504 \\
(0.1511)^{* * *}\end{array}$ \\
\hline Long_real_r & $\begin{array}{l}0.5762 \\
(0.1807)^{* * *}\end{array}$ & $\begin{array}{l}0.5282 \\
(0.1786)^{* * *}\end{array}$ & $\begin{array}{l}0.5718 \\
(0.1924)^{* * *}\end{array}$ & $\begin{array}{l}0.5907 \\
(0.1937)^{* * *}\end{array}$ & $\begin{array}{l}0.5543 \\
(0.1870)^{* * *}\end{array}$ \\
\hline Trade_open & $0.1520(0.1029)$ & $0.1402(0.0819)^{*}$ & $0.1238(0.1039)$ & $\begin{array}{l}0.0805 \\
(0.0963)\end{array}$ & $\begin{array}{l}0.1766 \\
(0.0976)^{*}\end{array}$ \\
\hline popd & $0.0944(0.0720)$ & $0.0198(0.0563)$ & $0.0245(0.0582)$ & $\begin{array}{l}0.0350 \\
(0.0570) \\
\end{array}$ & $\begin{array}{l}0.0309 \\
(0.0665) \\
\end{array}$ \\
\hline R square & 0.9765 & 0.9776 & 0.9755 & 0.9752 & 0.9768 \\
\hline $\mathrm{N}$ & 353 & 353 & 353 & 353 & 353 \\
\hline
\end{tabular}

Table 8 The results of Final Models for Youth Unemployment Rate

\begin{tabular}{|c|c|c|c|c|c|}
\hline & youth_unem2 & Youth_unem2 & Youth_unem2 & Youth_unem2 & Youth_unem2 \\
\hline Income_support & $\begin{array}{l}0.5665 \\
(0.1640)^{* * *}\end{array}$ & & & & \\
\hline Pension_exp & & $\begin{array}{l}0.6545 \\
(0.1952)^{* * *}\end{array}$ & & & \\
\hline Health_exp & & & $0.6105(0.3803)$ & & \\
\hline otherwelf & & & & $\begin{array}{l}-0.2054 \\
(0.4467)\end{array}$ & \\
\hline Public_social & & & & & $\begin{array}{l}0.2469 \\
(0.0725)^{* * *}\end{array}$ \\
\hline $\begin{array}{l}\text { One year lagged } \\
\text { value of } \\
\text { youth_unem2 }\end{array}$ & $\begin{array}{l}0.7815 \\
(0.0414)^{* * *}\end{array}$ & $\begin{array}{l}0.7506 \\
(0.0416)^{* * *}\end{array}$ & $\begin{array}{l}0.8009 \\
(0.0359)^{* * *}\end{array}$ & $\begin{array}{l}0.7911 \\
(0.0416)^{* * *}\end{array}$ & $\begin{array}{l}0.7740 \\
(0.0397)^{* * *}\end{array}$ \\
\hline Labor_prodg & $0.0718(0.0825)$ & $0.1399(0.0927)$ & $0.1132(0.0830)$ & $\begin{array}{l}0.1004 \\
(0.0835)\end{array}$ & $\begin{array}{l}0.1035 \\
(0.0862)\end{array}$ \\
\hline dtot & $-0.0109(0.0869)$ & $0.0147(0.0709)$ & $-0.0051(0.0725)$ & $\begin{array}{l}-0.0180 \\
(0.0713)\end{array}$ & $\begin{array}{l}0.0056 \\
(0.0802)\end{array}$ \\
\hline inflation & $-0.0016(0.0420)$ & $0.0028(0.0485)^{*}$ & $-0.0237(0.0447)$ & $\begin{array}{l}-0.0257 \\
(0.0379)\end{array}$ & $\begin{array}{l}0.0017 \\
(0.0447)\end{array}$ \\
\hline Long_real_r & $0.0823(0.0918)$ & $0.1014(0.0929)$ & $0.1011(0.0887)$ & $\begin{array}{l}0.1097 \\
(0.0922)\end{array}$ & $0.0888(0.0916)$ \\
\hline Trade_open & $\begin{array}{l}-0.1080 \\
(0.0347)^{* * *}\end{array}$ & $\begin{array}{l}-0.1199 \\
(0.0402)^{* * *}\end{array}$ & $\begin{array}{l}-0.1056 \\
(0.0404)^{* * *}\end{array}$ & $\begin{array}{l}-0.1371 \\
(0.0446)^{* * *}\end{array}$ & $\begin{array}{l}-0.1021 \\
(0.0374)^{* * *}\end{array}$ \\
\hline popd & $\begin{array}{l}0.1032 \\
(0.0331)^{* * *}\end{array}$ & $\begin{array}{l}0.0773 \\
(0.0276)^{* * *}\end{array}$ & $\begin{array}{l}0.0771 \\
(0.0269)^{* * *}\end{array}$ & $\begin{array}{l}0.0862 \\
(0.0407)^{* *}\end{array}$ & $\begin{array}{l}0.0787 \\
(0.0287)^{* * *}\end{array}$ \\
\hline R square & 0.9647 & 0.9641 & 0.9639 & 0.9632 & 0.9643 \\
\hline $\mathrm{N}$ & 375 & 375 & 375 & 375 & 375 \\
\hline
\end{tabular}


Table 9 The results of Final Models for Investment Rate

\begin{tabular}{|c|c|c|c|c|c|}
\hline & invrate & invrate & invrate & invrate & invrate \\
\hline Income_support & $-0.4790(0.2269)^{* *}$ & & & & \\
\hline Pension_exp & & $-0.7908(0.3080)^{* *}$ & & & \\
\hline Health_exp & & & $-0.2697(0.4739)$ & & \\
\hline otherwelf & & & & $\begin{array}{l}-0.3081 \\
(0.4781)\end{array}$ & \\
\hline Public_social & & & & & $\begin{array}{l}-0.2854 \\
(0.1259)^{* *}\end{array}$ \\
\hline inflation & $0.1206(0.0959)$ & $0.1580(0.1011)$ & $0.1755(0.0952)^{*}$ & $\begin{array}{l}0.1627 \\
(0.0910)^{*}\end{array}$ & $\begin{array}{l}0.1351 \\
(0.0965)\end{array}$ \\
\hline Long_real_r & $-0.2414(0.1377)^{*}$ & $-0.2833(0.1423)^{*}$ & $-0.2957(0.1416)^{* *}$ & $\begin{array}{l}-0.2874 \\
(0.1386)^{* *}\end{array}$ & $\begin{array}{l}-0.2539 \\
(0.1339) *\end{array}$ \\
\hline Trade_open & $-0.0318(0.0469)$ & $-0.0608(0.0389)$ & $-0.0403(0.0494)$ & $\begin{array}{l}-0.0330 \\
(0.0430)\end{array}$ & $\begin{array}{l}-0.0549 \\
(0.0391)\end{array}$ \\
\hline R square & 0.6930 & 0.7059 & 0.6836 & 0.6841 & 0.6997 \\
\hline $\mathrm{N}$ & 564 & 562 & 562 & 562 & 562 \\
\hline
\end{tabular}

Table 10 Sensitivity analysis

\begin{tabular}{|c|c|c|c|c|c|c|}
\hline & unemp & unemp & unemp & unemp & unemp & unemp \\
\hline Income_support & $\begin{array}{l}0.3962 \\
(0.1162)^{* * *}\end{array}$ & & & & & \\
\hline Pension_exp & & $\begin{array}{l}0.4343 \\
(0.0989)^{* * *}\end{array}$ & & & & \\
\hline Health_exp & & & $0.2815(0.1961)$ & & & \\
\hline otherwelf & & & & $\begin{array}{l}0.1744 \\
(0.1925)\end{array}$ & & \\
\hline Public_social & & & & & $\begin{array}{l}0.1818 \\
(0.0523)^{* * *}\end{array}$ & \\
\hline govexp & & & & & & $\begin{array}{l}0.3714 \\
(0.1016)^{* * *}\end{array}$ \\
\hline $\begin{array}{l}\text { One year lagged } \\
\text { value of unemp }\end{array}$ & $\begin{array}{l}0.6885 \\
(0.0349)^{* * *}\end{array}$ & $\begin{array}{l}0.6526 \\
(0.0374)^{* * *}\end{array}$ & $\begin{array}{l}0.7181 \\
(0.0431)^{* * *}\end{array}$ & $\begin{array}{l}0.6873 \\
(0.0329)^{* * *}\end{array}$ & $\begin{array}{l}0.6822 \\
(0.0348)^{* * *}\end{array}$ & $\begin{array}{l}0.6781 \\
(0.0346)^{* * *}\end{array}$ \\
\hline migrate & $\begin{array}{l}-0.0955 \\
(0.0268)^{* * *}\end{array}$ & $\begin{array}{l}-0.0804 \\
(0.0243)^{* * *}\end{array}$ & $\begin{array}{l}-0.0880 \\
(0.0230)^{* * *}\end{array}$ & $\begin{array}{l}-0.0939 \\
(0.0232)^{* * *}\end{array}$ & $\begin{array}{l}-0.0889 \\
(0.0237)^{* * *}\end{array}$ & $\begin{array}{l}-0.0922 \\
(0.0210)^{* * *}\end{array}$ \\
\hline mf_prodg & $0.0058(0.0374)$ & $0.0552(0.0443)$ & $0.0216(0.0387)$ & $\begin{array}{l}0.0138 \\
(0.0405)\end{array}$ & $\begin{array}{l}0.0405 \\
(0.0380)\end{array}$ & $\begin{array}{l}0.0711 \\
(0.0417)^{*}\end{array}$ \\
\hline Idtot & $-0.1032(0.0568)^{*}$ & $-0.0803(0.0504)$ & $-0.0958(0.0510)^{*}$ & $\begin{array}{l}-0.0971 \\
(0.0443)^{* *}\end{array}$ & $\begin{array}{l}-0.0859 \\
(0.0542)\end{array}$ & $\begin{array}{l}-0.0171 \\
(0.0487)\end{array}$ \\
\hline inflation & $\begin{array}{l}-0.0943 \\
(0.0408)^{* *}\end{array}$ & $\begin{array}{l}-0.1308 \\
(0.0483)^{* * *}\end{array}$ & $\begin{array}{l}-0.1061 \\
(0.0349)^{* * *}\end{array}$ & $\begin{array}{l}-0.1064 \\
(0.0424)^{* *}\end{array}$ & $\begin{array}{l}-0.0942 \\
(0.0434)^{* *}\end{array}$ & $\begin{array}{l}-0.0698 \\
(0.0499)\end{array}$ \\
\hline Long_real_r & $\begin{array}{l}0.1615 \\
(0.0372)^{* * *}\end{array}$ & $\begin{array}{l}0.2213 \\
(0.0393)^{* * *}\end{array}$ & $\begin{array}{l}0.2063 \\
(0.0390)^{* * *}\end{array}$ & $\begin{array}{l}0.2027 \\
(0.0424)^{* * *}\end{array}$ & $\begin{array}{l}0.1830 \\
(0.0321)^{* * *}\end{array}$ & $\begin{array}{l}0.1939 \\
(0.0324)^{* * *}\end{array}$ \\
\hline Trade_open & $-0.0053(0.0177)$ & $-0.0197(0.0136)$ & $-0.0140(0.0178)$ & $\begin{array}{l}-0.0237 \\
(0.0179)\end{array}$ & $\begin{array}{l}0.0002 \\
(0.0183)\end{array}$ & $\begin{array}{l}-0.0029 \\
(0.0212)\end{array}$ \\
\hline popd & $\begin{array}{l}0.0357 \\
(0.0108)^{* * *}\end{array}$ & $0.0127(0.0072)^{*}$ & $0.0064(0.0075)$ & $\begin{array}{l}-0.0001 \\
(0.0102)\end{array}$ & $\begin{array}{l}0.0178 \\
(0.0092)^{*}\end{array}$ & $\begin{array}{l}-0.0088 \\
(0.0084)\end{array}$ \\
\hline R square & 0.9686 & 0.9666 & 0.9645 & 0.9632 & 0.9681 & 0.9669 \\
\hline $\mathrm{N}$ & 311 & 311 & 311 & 311 & 311 & 279 \\
\hline
\end{tabular}

Note: T-statistics based on robust clustered standard errors in parenthesis. ${ }^{*}, * * * *$ denote significance at 10 percent, 5 percent, and 1 percent, respectively. All the regressions are IV regressions with two IVs to instrument the lagged value of response variable: twoyear and three-year lagged values of the response variable. All the regressions include fixed effects of both year and country. 


\section{Reference}

Adema, W.(2001), .Net social expenditure, 2nd Edition., OECD Labour market and social policy, Occasional paper, No. 52.

Agell, J., Lindh, T., Ohlsson, H., 1997. Growth and the public sector: a critical review essay. European Journal of Political Economy 13, 33-52

Alesina, Alberto; Perotti, Roberto (1994), The Welfare State and Competitiveness, NBER Working Paper No. 4810, Issued in July 1994

Angrist, Joshua D. and Krueger, Alan B (2001), Instrumental Variables and the Search for Identification: From Supply and Demand to Natural Experiments, Journal of Economic Perspectives, Volume 15, Number 4, Fall 200, Pages 69-85

Atkinson, A B (1995), The welfare state and economic performance, National Tax Journal, Vol. 48, no. 2, (June 1995), pp. 171-98

Atkinson, A. B. (1995). Incomes and the Welfare State. Cambridge: Cambridge University Press. ISBN 0-521-55796-8.

Baker, Dean; Glyn Andrew; Howell, David; Schmitt, John (2002), Labor Market Institutions and Unemployment: A Critical Assessment of the Cross-Country Evidence, CEPA Working Paper 2002-17, November 8, 2002

Baker, Dean; Glyn Andrew; Howell, David; Schmitt, John (2004), Unemployment and Labour Market Institutions: The Failure of the Empirical Case for Deregulation, Working Paper No. 43, International Labor Organization, November 2004

Barro, Robert J.; McCleary, Rachel M. (2003), Religion And Economic Growth, NBER Working Paper 9682, http://www.nber.org/papers/w9682, May 2003 
Bernal-Verdugo, Lorenzo E; Furceri, Davide; and Guillaume, Dominique (2012), Labor Market Flexibility and Unemployment: New Empirical Evidence of Static and Dynamic Effects, IMF working paper 12/64

Beraldo, Sergio; Montolio, Daniel; Turati Gilberto (2009), Healthy, educated and wealthy: A primer on the impact of public and private welfare expenditures on economic growth, Journal of Socio-Economics 38 (2009) 946-956

Davidson, R. and J. G. MacKinnon (1993), Estimation and Inference in Econometrics. New York: Oxford University Press.

Disney, Richard (2000), The impact of tax and welfare policies on employment and unemployment in OECD countries, IMF working paper, WP00/164

Felbermayr, Gabriel; Prat, Julienne; Schmerer,Hans-Jörg (2009), Trade and Unemployment: What Do the Data Say? IZA Discussion Paper No. 4184, May 2009, http://ftp.iza.org/dp4184.pdf

Grier, K., Tullock, G. (1989), An Empirical Analysis of Cross-national Economic Growth, 1951-80, Journal of Monetary Economics, pp. 259-276

Headey, Bruce; Goodin, Robert E. ; Muffels, Ruud and Dirven, Henk-Jan (2000), Is There a Trade-Off Between Economic Efficiency and a Generous Welfare State? A Comparison of Best Cases of 'The Three Worlds of Welfare Capitalism', Social Indicators Research, Volume 50, Number 2, 115-157, 2000

IMF (2003), World Economic Outlook, April 2003, Chapter IV: Unemployment and Labor Market Institutions: Why Reforms Pay Off

James J. Heckman, 2007. "Comments on Are Protective Labor Market Institutions at the Root of Unemployment? A Critical Review of the Evidence by David Howell, Dean 
Baker, Andrew Glyn, and John Schmitt," Capitalism and Society, Berkeley Electronic Press, vol. 2(1), pages 5.

Lindert, Peter H, "Why the Welfare State Looks Like a Free Lunch", NBER Working Paper No. 9869, Issued in July 2003

Ljungqvist, Lars; Sargent, Thomas J, Welfare States and Unemployment, journal of Economic Theory, Volume (Year): 6 (1995), pp. 143-60

Muysken, J.; Ziesemer, T.H.W.(2011). The effect of net immigration on economic growth in an ageing economy: transitory and permanent shocks, UNU-MERIT Working Papers, http://www.merit.unu.edu/publications/wppdf/2011/wp2011-055.pdf

Nickell, Stephen (1997), Unemployment and labor market rigidities: Europe versus North America", Journal of Economic Perspectives, Vol. II (Summer), pp. 55-74

OECD (2006): OECD Employment Outlook: Boosting Jobs and Incomes, ISBN 92-6402384-4, C OECD 2006

OECD (2011): SOCIETY AT A GLANCE 2011: OECD SOCIAL INDICATORS, http://www.oecd.org/dataoecd/27/60/47570121.pdf

OECD Factbook2010, http://www.oecd-ilibrary.org/economics/oecd-factbook_18147364

OECD Social Expenditure Database (SOCX), http://stats.oecd.org/Index.aspx?datasetcode=SOCX_AGG

Scarpetta, Stefano (1996), Assessing the role of labor market policies and institutional settings on unemployment: A cross-country study, OECD Economic Study, No. 26

Stefan Folster, Magnus Henrekson (199), "Growth and the public sector: a critique of the critics", European Journal of Political Economy Vol. 15(1999) 337-358

Stock, James H. and Motohiro Yogo (2005), "Testing for Weak Instruments in Linear IV Regression." Ch. 5 in J.H. Stock and D.W.K. Andrews (eds), Identification and Inference 
for Econometric Models: Essays in Honor of Thomas J. Rothenberg, Cambridge University Press. Originally published 2001 as NBER Technical Working Paper No. 284; newer version (2004) available at Stock's website.

Tullio, Gisseppe (1987), "Long run implications of the increase in taxation and public debt for employment and economic growth in Europe", European Economic Review, Vol. 31(April), pp. 741-80

Wooldridge, Jeffrey M. (2001), Econometric Analysis of Cross Section and Panel Data, The MIT Press, Cambridge, Massachusetts; London, England, October 2001 


\title{
APPENDIX
}

\section{STATA program for the paper "Unemployment and Welfare State: What do the Data Tell Us?"}

\author{
Author: Hong Ding
}

insheet using "C: \data \personal \paper\welfare_growth_dummy_final.csv", comma

xtset id year1

sort id year 1

drop ltot dtot ldtot dtot2 lprodg lunemp 12unem 13unem

by id: gen ltot=1.terms_of_trade

by id: gen dtot $=(\log ($ terms_of_trade $)-\log (1$ tot $)) *$ trade_open

by id: gen ldtot=1.dtot

by id: gen dtot $2=($ terms_of_trade-ltot $) /$ ltot

by id: gen lprodg=l.prodg

by id: gen lunemp=l. unemp

by id: gen I2unem=I2.unemp

by id: gen I3unem=|3.unemp

$\star * * *$ The following derived variables are already in the dataset**************

by id: gen dunem=d.unemp

by id: gen ldunem=l. dunem

by id: gen llabor_prodg=l.labor_prodg

by id: gen lmf_prodg=l.mf_prodg

by id: gen lead_inflation=inflation[_n+1]

by id: gen long_real_r=long_r-lead_inflation

by id: gen 1_lunem=1.long_unem2

by id: gen 12_lunem=12.1ong_unem2

by id: gen 13_lunem=13.1ong_unem2

by id: gen d_lunem=d.long_unem2

by id: gen 1_d_lunem=1.d_lunem 
by id: gen lnopen $=\log ($ trade_open $)$

by id: gen $\operatorname{lnpopd}=\log (\mathrm{popd})$

by id: gen 1_yunem=1.youth_unem2

by id: gen 12_yunem=12.youth_unem2

by id: gen 13_yunem=l3.youth_unem2

by id: gen d yunem=d.youth unem2

by id: gen 1_d_yunem=l.d_yunem

\section{IV relevance and strength test:}

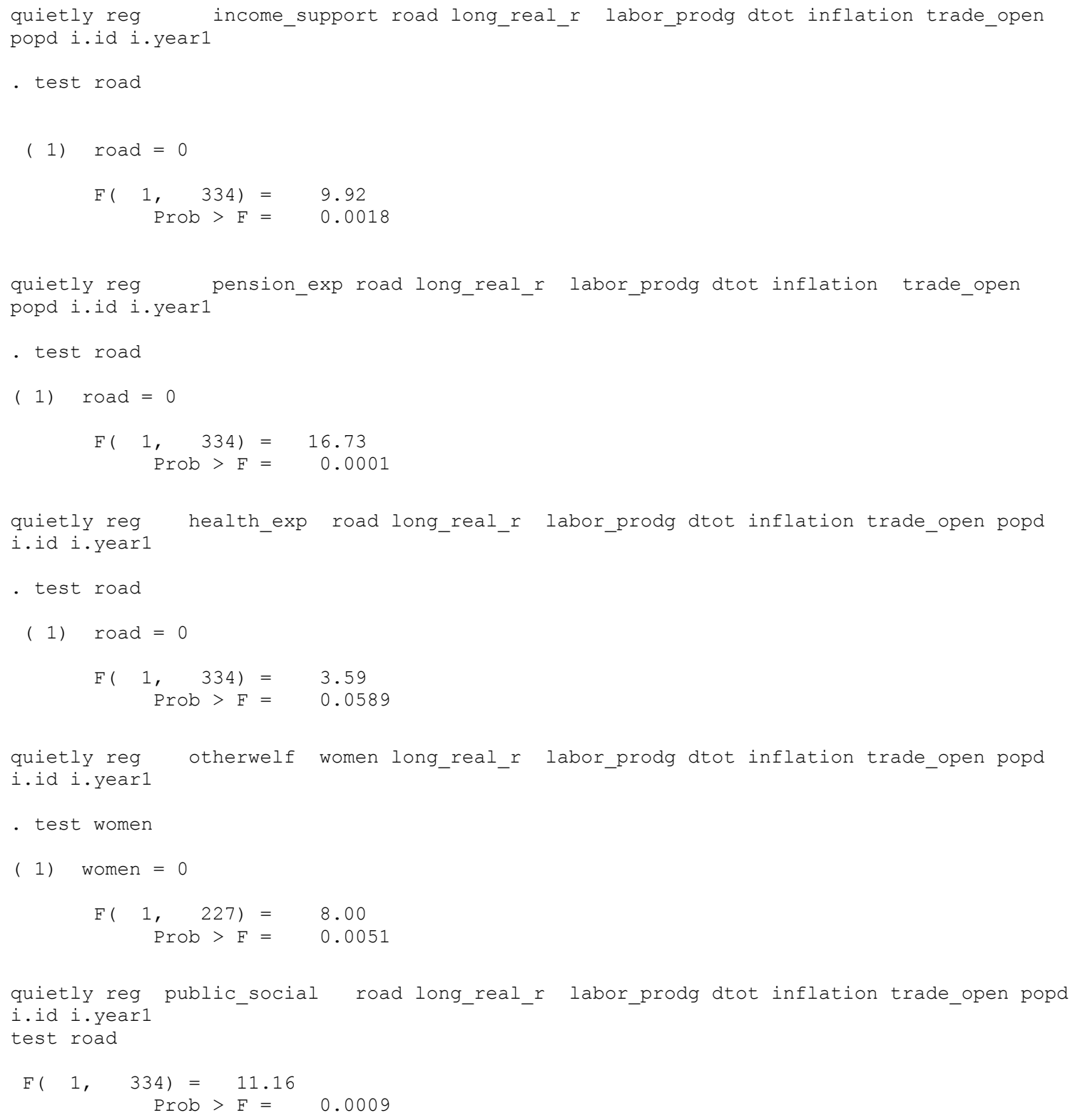




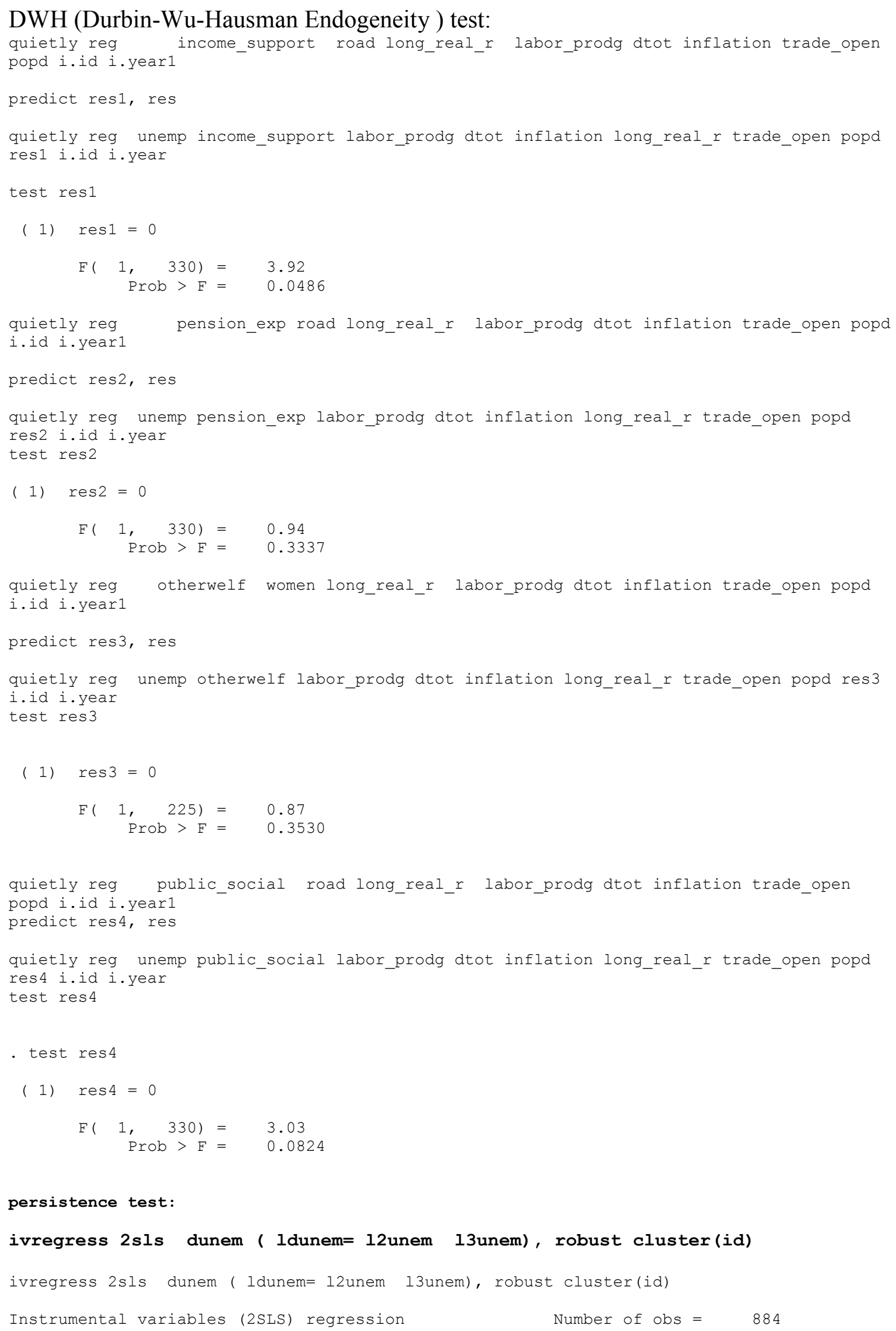




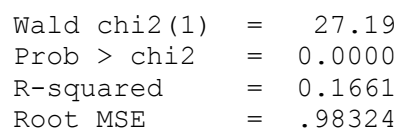

(Std. Err. adjusted for 33 clusters in id)

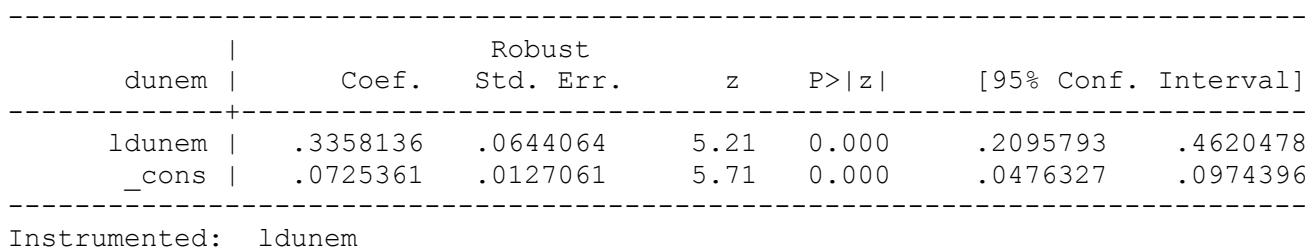

Instruments: $\quad$ l2unem l3unem

ivregress 2sls dunem ( ldunem= l2unem l3unem) if year $1==2008$

Instrumental variables (2SLS) regression $\quad$ Number of obs = 30

Wald $\operatorname{chi2}(1)=16.13$

Prob $>$ chi2 $=0.0001$

$\mathrm{R}$-squared $=0.4373$

Root MSE $=.70779$

\begin{tabular}{|c|c|c|c|c|c|c|}
\hline dunem & Coef. & Std. Err. & z & $P>|z|$ & [95\% Conf. & Interval] \\
\hline---------- & -------1 & $---1----1$ & --ー-ー & ----- & ---------1 & - - - - - - - \\
\hline Idunem & .6689215 & .1665613 & 4.02 & 0.000 & .3424673 & .9953757 \\
\hline _cons & .3530412 & .1665505 & 2.12 & 0.034 & .0266083 & .6794741 \\
\hline $\begin{array}{l}\text { Instrumented: } \\
\text { Instruments: }\end{array}$ & $\begin{array}{l}\text { lunem } \\
\text { unem } 1\end{array}$ & & & & & \\
\hline
\end{tabular}


Long-term unemployment rate:

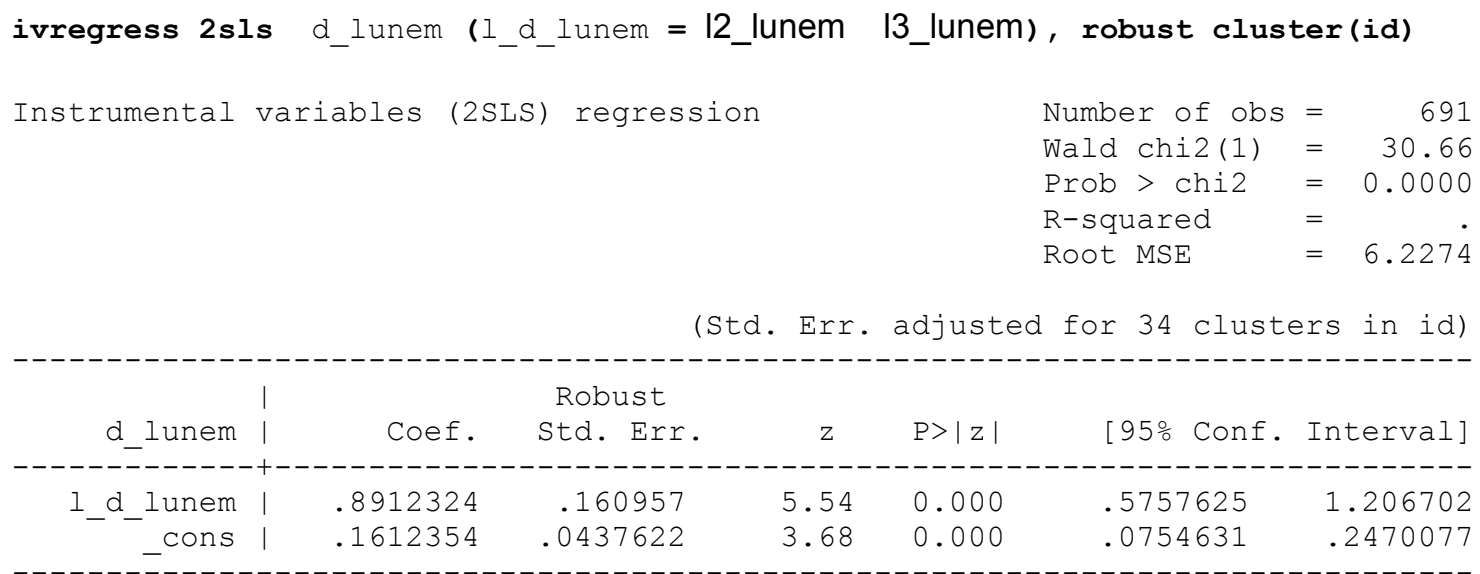

\section{DWH test:}

quietly reg income_support road long_real_r labor_prodg dtot inflation trade_open popd i.id i.year 1

predict res1, res

quietly reg long_unem2 income_support labor_prodg dtot inflation long_real_r trade_open popd resi i.id i.year

test res 1

quietly reg pension_exp road long_real_r labor_prodg dtot inflation trade_open popd i.id i.year 1

predict res2, res

quietly reg long_unem2 pension_exp labor_prodg dtot inflation long_real_r trade_open popd res 2 i.id i.year

test res2

quietly reg otherwelf women long_real_r labor_prodg dtot inflation trade_open popd i.id i.year 1

predict res3, res

quietly reg long unem2 otherwelf labor prodg dtot inflation long_real_r trade_open popd res3 i.id i.year

test res3

quietly reg public_social road long_real_r labor_prodg dtot inflation trade_open popd i.id i.year1

predict res4, res

quietly reg long_unem2 public_social labor_prodg dtot inflation long_real_r trade_open popd res4 i.id i.year

test res 4 


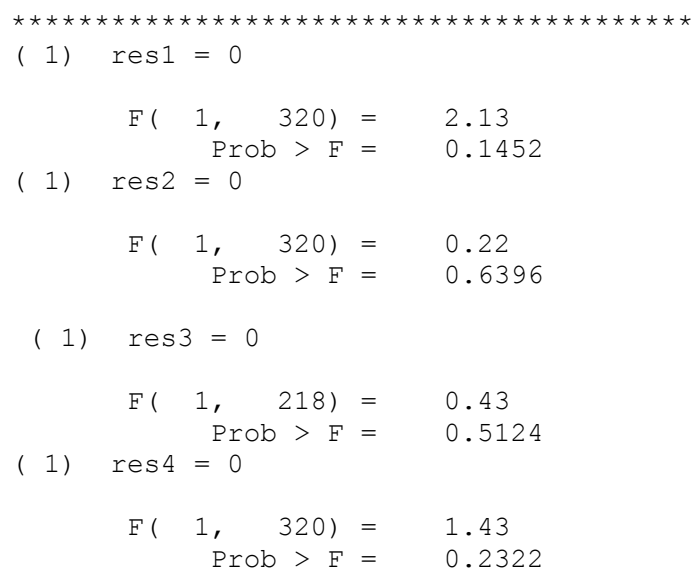


Youth unemployment rate:

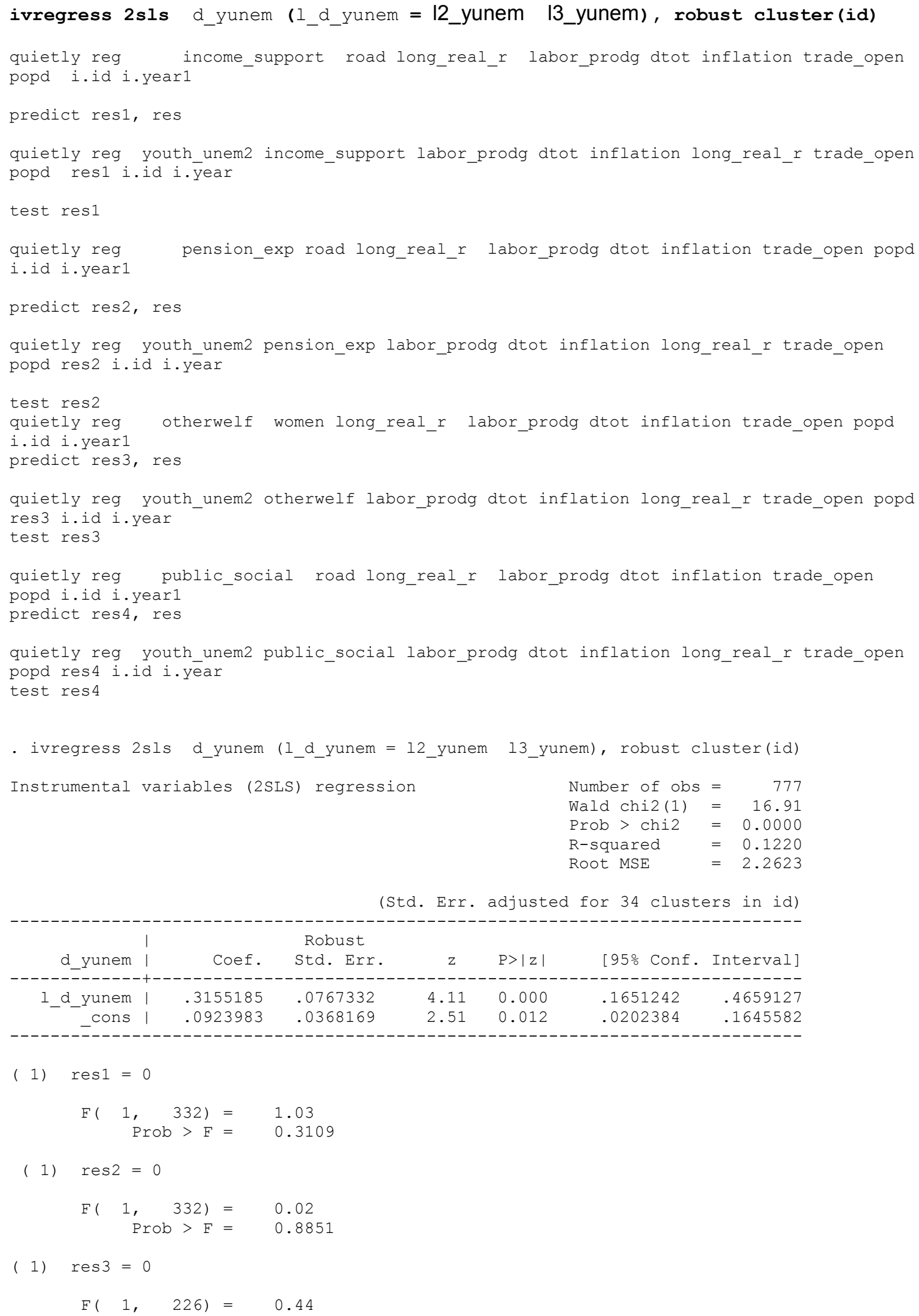

(Std. Err. adjusted for 34 clusters in id)

\begin{tabular}{|c|c|c|c|c|c|c|}
\hline d_yunem & Coef. & $\begin{array}{l}\text { Robust } \\
\text { Std. Err. }\end{array}$ & z & $P>|z|$ & [95\% Conf. & Interval] \\
\hline $\begin{array}{r}\text { I_d_yunem } \\
\text { cons }\end{array}$ & $\begin{array}{l}.3155185 \\
.0923983\end{array}$ & $\begin{array}{l}.0767332 \\
.0368169\end{array}$ & $\begin{array}{l}4.11 \\
2.51\end{array}$ & $\begin{array}{l}0.000 \\
0.012\end{array}$ & $\begin{array}{l}.1651242 \\
.0202384\end{array}$ & $\begin{array}{r}.4659127 \\
.1645582\end{array}$ \\
\hline
\end{tabular}

( 1$) \quad \operatorname{res} 1=0$

$$
F(1,332)=1.03
$$$$
\text { Prob }>F=0.3109
$$

( 1$)$ res $2=0$

$$
\begin{array}{rll}
\mathrm{F}(1,332) & = & 0.02 \\
\text { Prob }>\mathrm{F} & = & 0.8851
\end{array}
$$

( 1$) \operatorname{res} 3=0$

$$
F(1,226)=0.44
$$


Prob $>F=0.5095$

( 1$) \quad$ res $4=0$

$F(1,332)=0.72$

Prob $>\mathrm{F}=0.3982$ 
Final model:

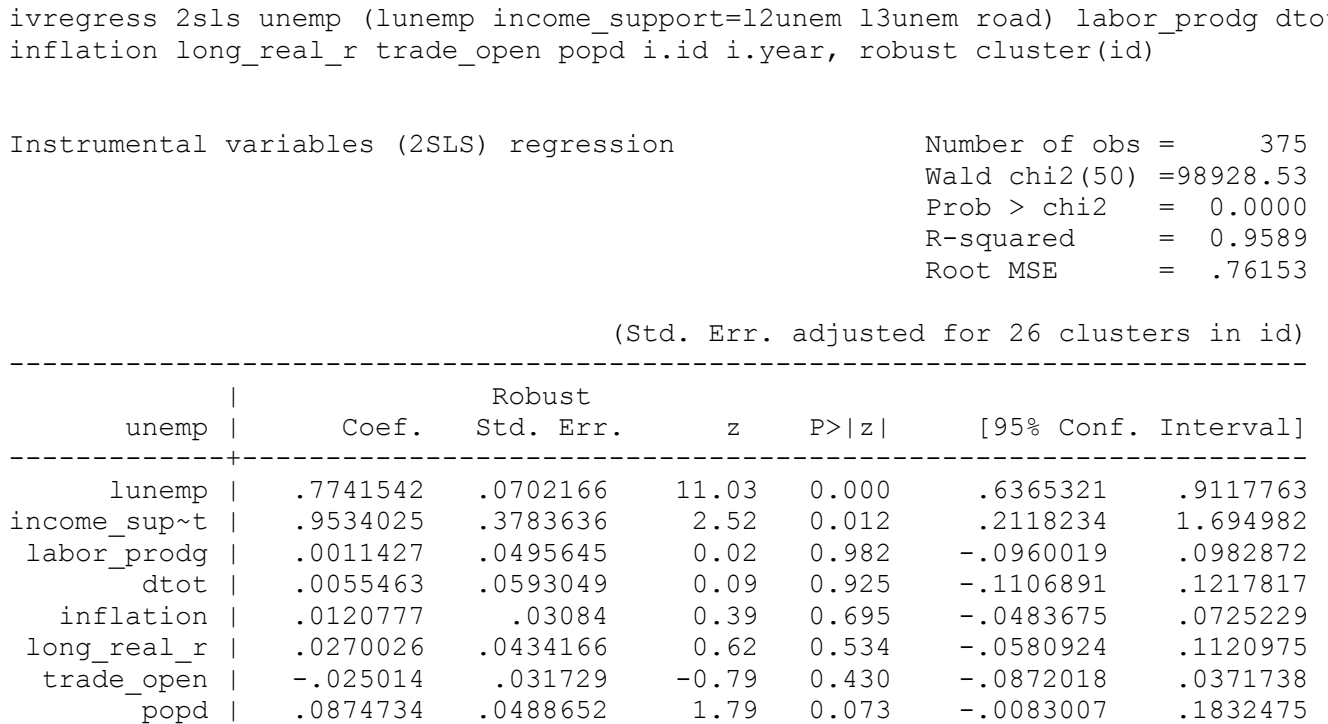

ivregress $2 \mathrm{sls}$ unemp (lunemp =l2unem l3unem) pension exp labor prodg dtot inflation long_real_r trade_open popd i.id i.year, robust cluster(id)

Instrumental variables (2SLS) regression

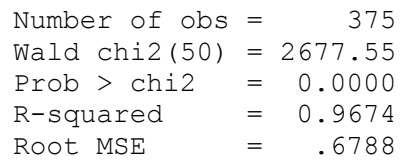

(Std. Err. adjusted for 26 clusters in id)

\begin{tabular}{|c|c|c|c|c|c|c|}
\hline & \multicolumn{6}{|c|}{ Robust } \\
\hline & Coef. & Std. Err. & z & $P>|z|$ & [95\% Conf. & Interval] \\
\hline lunemp & .7342957 & .0306684 & 23.94 & 0.000 & .6741867 & .7944046 \\
\hline pension exp & .4428674 & .1077885 & 4.11 & 0.000 & .2316058 & .6541289 \\
\hline labor p'rodg & .0798916 & .0413435 & 1.93 & 0.053 & -.0011402 & .1609235 \\
\hline dtot & .0244706 & .0276283 & 0.89 & 0.376 & -.0296798 & .078621 \\
\hline inflation & -.0089058 & .0229309 & -0.39 & 0.698 & -.0538496 & .036038 \\
\hline long real $r$ & .0667577 & .0417892 & 1.60 & 0.110 & -.0151476 & .148663 \\
\hline trade open & -.0572864 & .0180572 & -3.17 & 0.002 & -.0926778 & -.021895 \\
\hline popd & .0436688 & .0133929 & 3.26 & 0.001 & .0174191 & .0699184 \\
\hline
\end{tabular}

ivregress $2 \mathrm{sls}$ unemp (lunemp $=12$ unem l3unem) health exp labor prodg dtot inflation long_real_r trade_open popd i.id i.year, robust cluster(id) 
(Std. Err. adjusted for 26 clusters in id)

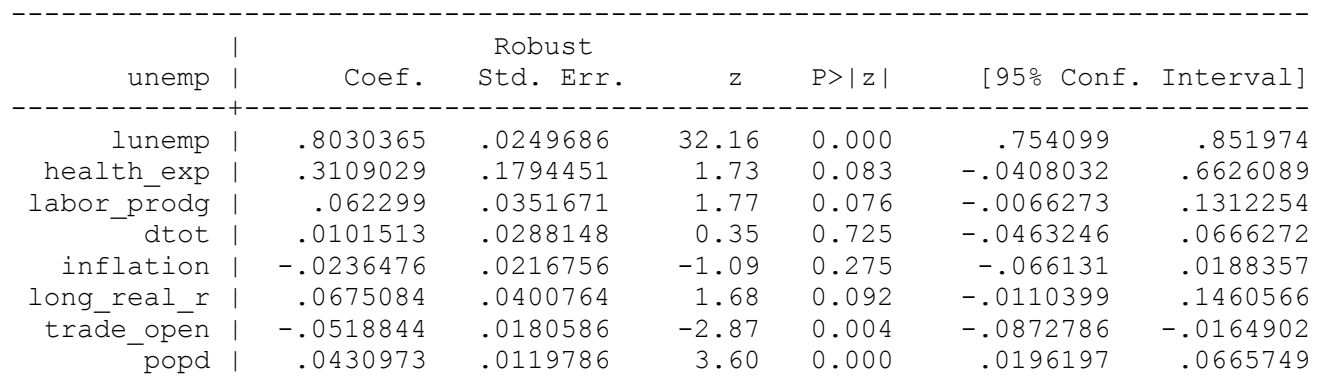

ivregress 2 sls unemp (lunemp $=12$ unem l3unem) otherwelf labor_prodg dtot inflation long_real_r trade_open popd i.id i.year, robust cluster(id)

(Std. Err. adjusted for 26 clusters in id)

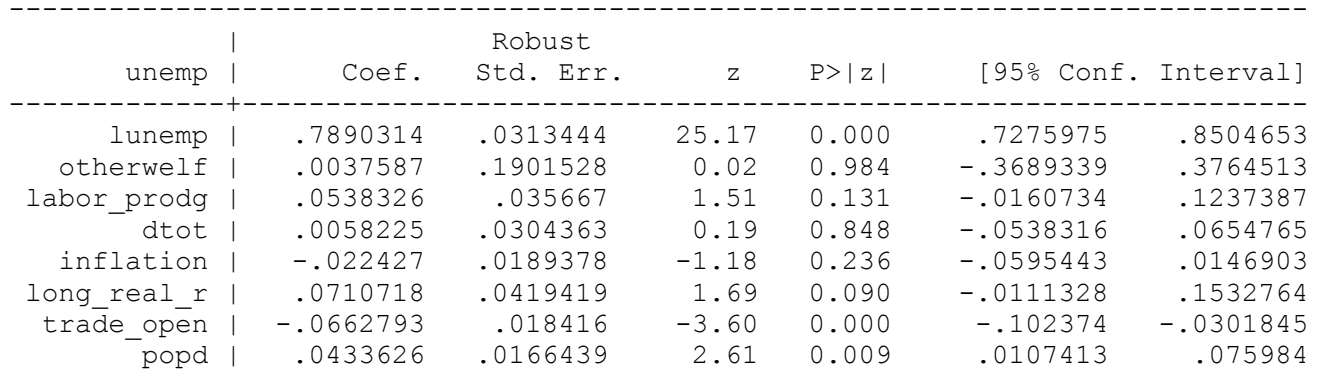

ivregress $2 \mathrm{sls}$ unemp (lunemp $=12$ unem l3unem) public social labor prodg dtot inflation long_real_r trade_open popd i.id i.year, robust cluster(id)

(Std. Err. adjusted for 26 clusters in id)

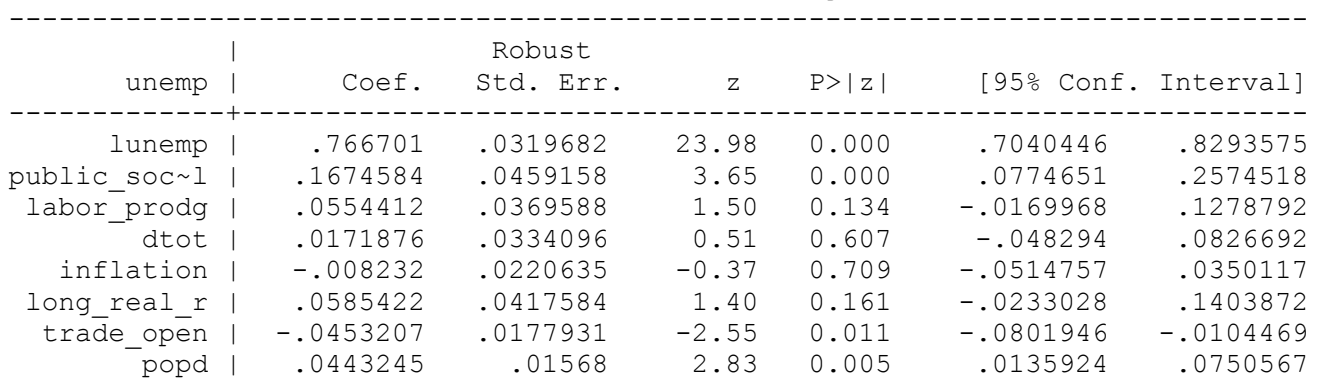

ivregress 2sls unemp (lunemp public_social =l2unem 13 unem road) labor_prodg dtot inflation long real r trade open popd i.id i.year, robust cluster(id)

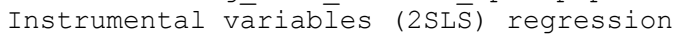


$\begin{array}{ll}\text { R-squared } & =0.9513 \\ \text { Root MSE } & =.82885\end{array}$

(Std. Err. adjusted for 26 clusters in id)

\begin{tabular}{|c|c|c|c|c|c|c|c|}
\hline unemp & 1 & Coef. & $\begin{array}{l}\text { Robust } \\
\text { Std. Err. }\end{array}$ & z & $P>|z|$ & [95\% Conf. & Interval] \\
\hline lunemp & | & .7282918 & .0754178 & 9.66 & 0.000 & .5804756 & .8761079 \\
\hline public_soc 1 & i & .518727 & .2346442 & 2.21 & 0.027 & .0588328 & .9786212 \\
\hline labor_prodg & 1 & .0579023 & .0476154 & 1.22 & 0.224 & -.0354222 & .1512268 \\
\hline dtot & 1 & .0415089 & .0564746 & 0.74 & 0.462 & -.0691794 & .1521971 \\
\hline inflation & | & .0234542 & .0380503 & 0.62 & 0.538 & -.0511231 & .0980315 \\
\hline long_real_r & | & .0308355 & .0465238 & 0.66 & 0.507 & -.0603495 & .1220205 \\
\hline trade_open & | & -.0013795 & .0412848 & -0.03 & 0.973 & -.0822963 & .0795372 \\
\hline popd & | & .0467045 & .0537852 & 0.87 & 0.385 & -.0587125 & .1521215 \\
\hline
\end{tabular}


Results for Long unemployment rate:

ivregress 2sls long_unem2 (1_lunem = 12_lunem 13_lunem) income_support labor_prodg dtot inflation long_real_r trade_open popd i.id i.year, robust cluster(id)

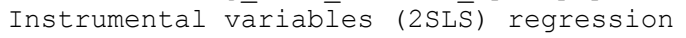

$\begin{array}{llr}\text { Number of obs } & = & 353 \\ \text { Wald chi2 }(50) & = & 6.7 e+07 \\ \text { Prob > chi2 } & =0.0000 \\ \text { R-squared } & =0.9765 \\ \text { Root MSE } & =2.7082\end{array}$

(Std. Err. adjusted for 26 clusters in id)

\begin{tabular}{|c|c|c|c|c|c|c|}
\hline long unem2 & Coef. & $\begin{array}{l}\text { Robust } \\
\text { Std. Err. }\end{array}$ & $\mathrm{z}$ & $P>|z|$ & [95\% Conf. & Interval] \\
\hline------- & ---------- & ---------- & ------ & ----- & -------1 & ---------- \\
\hline 1_lunem & .7320259 & .057333 & 12.77 & 0.000 & .6196552 & .8443966 \\
\hline income_sup t & 1.317862 & .4043498 & 3.26 & 0.001 & .525351 & 2.110373 \\
\hline labor_prodg & .1882131 & .1113391 & 1.69 & 0.091 & -.0300074 & .4064337 \\
\hline dtot & -.0325074 & .0697008 & -0.47 & 0.641 & -.1691185 & .1041037 \\
\hline inflation & -.7067452 & .1607473 & -4.40 & 0.000 & -1.021804 & -.3916862 \\
\hline long_real_r & .5762228 & .1807229 & 3.19 & 0.001 & .2220124 & .9304332 \\
\hline trade_open & .1519685 & .1029486 & 1.48 & 0.140 & -.0498071 & .3537441 \\
\hline popd & .0943562 & .0719882 & 1.31 & 0.190 & -.046738 & .2354504 \\
\hline
\end{tabular}

ivregress 2sls long_unem2 (1_lunem = 12_lunem 13_lunem) pension_exp labor_prodg dtot inflation long_real_r trade_open popd i.id i.year, robust cluster(id)

(Std. Err. adjusted for 26 clusters in id)

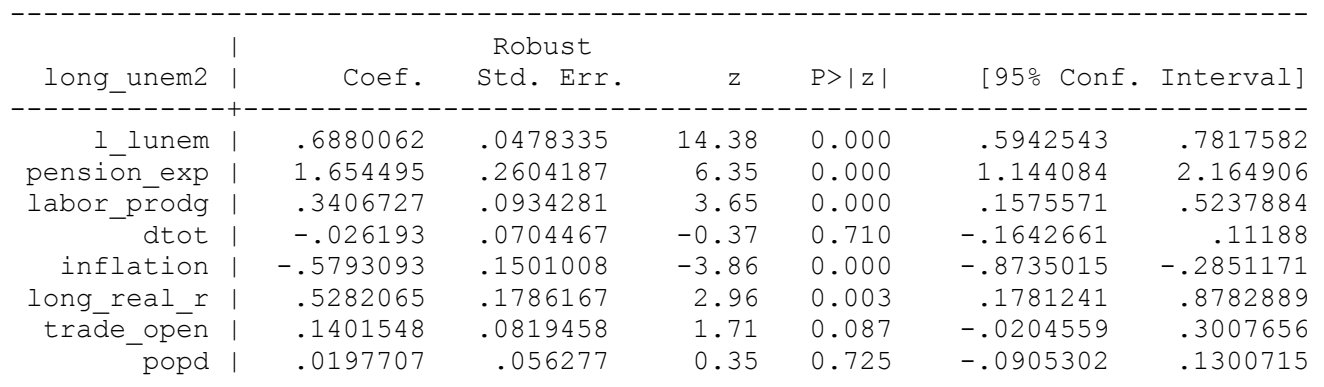

ivregress 2sls long_unem2 (1_lunem = 12_lunem 13_lunem) health_exp labor_prodg dtot inflation long_real_r trade_open popd i.id i.year, robust cluster(id)

Instrumental variables (2SLS) regression

$\begin{array}{llr}\text { Number of obs } & =353 \\ \text { Wald chi2 }(50) & =9870.10 \\ \text { Prob > chi2 } & =0.0000 \\ \text { R-squared } & =0.9755 \\ \text { Root MSE } & =2.7681\end{array}$

(Std. Err. adjusted for 26 clusters in id)

\begin{tabular}{|c|c|c|c|c|c|c|}
\hline long_unem2 & Coef. & $\begin{array}{l}\text { Robust } \\
\text { Std. Err. }\end{array}$ & $\mathrm{z}$ & $\mathrm{P}>|\mathrm{z}|$ & [95\% Conf. & Interval] \\
\hline-----------1 & & ---------- & ---- & & ----------- & ---------- \\
\hline 1_lunem & .7336129 & .0545622 & 13.45 & 0.000 & .6266729 & .8405529 \\
\hline health_exp & .8738074 & .6301635 & 1.39 & 0.166 & -.3612903 & 2.108905 \\
\hline labor_prodg & .2646194 & .1064469 & 2.49 & 0.013 & .0559874 & .4732515 \\
\hline
\end{tabular}




\begin{tabular}{r|rrrrrr} 
dtot & -.0763265 & .0727534 & -1.05 & 0.294 & -.2189206 & .0662676 \\
inflation &.- .7282818 & .1579045 & -4.61 & 0.000 & -1.037769 & -.4187946 \\
long_real_r & .5718237 & .1924187 & 2.97 & 0.003 & .1946899 & .9489575 \\
trade_open & .1237764 & .1038968 & 1.19 & 0.234 & -.0798576 & .3274103 \\
popd & .0245113 & .0581563 & 0.42 & 0.673 & -.0894729 & .1384956
\end{tabular}

ivregress 2sls long_unem2 (1_lunem = 12_lunem 13_lunem) otherwelf labor_prodg dtot inflation long_real_r trade_open popd i.id i.year, robust cluster(id)

Instrumental variables (2SLS) regression

$\begin{array}{llr}\text { Number of obs } & =353 \\ \text { Wald chi2 }(50) & =1.7 e+05 \\ \text { Prob }>\text { chi2 } & =0.0000 \\ \text { R-squared } & =0.9752 \\ \text { Root MSE } & =2.7837\end{array}$

(Std. Err. adjusted for 26 clusters in id)

\begin{tabular}{|c|c|c|c|c|c|c|}
\hline & & Robust & & & & \\
\hline long_unem2 & Coef. & Std. Err. & z & $\mathrm{P}>|\mathrm{z}|$ & [95\% Conf. & Interval] \\
\hline 1 lunem & .7258509 & .0521257 & 13.93 & 0.000 & .6236863 & .8280154 \\
\hline othērwelf & -.2256364 & .4736192 & -0.48 & 0.634 & -1.153913 & .7026403 \\
\hline labor prodg & .239329 & .1128668 & 2.12 & 0.034 & .0181141 & .460544 \\
\hline dtot & -.1086318 & .0763188 & -1.42 & 0.155 & -.2582138 & .0409503 \\
\hline inflation & -.7299361 & .1588897 & -4.59 & 0.000 & -1.041354 & -.4185179 \\
\hline long_real_r & .5907381 & .1936602 & 3.05 & 0.002 & .2111711 & .9703052 \\
\hline trade_open & .0804536 & .0962893 & 0.84 & 0.403 & -.1082699 & .2691771 \\
\hline popd & .035029 & .0569873 & 0.61 & 0.539 & -.076664 & .146722 \\
\hline
\end{tabular}

ivregress 2sls long_unem2 (1_lunem = 12_lunem 13_lunem) public_social labor_prodg dtot inflation long_real_r trade_open popd i.id i.year, robust clustēr(id)

Instrumental variables (2SLS) regression

$\begin{array}{llr}\text { Number of obs } & =353 \\ \text { Wald chi2(50) } & =9924.05 \\ \text { Prob chi2 } & =0.0000 \\ \text { R-squared } & =0.9768 \\ \text { Root MSE } & =2.6904\end{array}$

(Std. Err. adjusted for 26 clusters in id)

\begin{tabular}{|c|c|c|c|c|c|c|}
\hline long_unem2 & Coef. & $\begin{array}{l}\text { Robust } \\
\text { Std. Err. }\end{array}$ & $z$ & $\mathrm{P}>|\mathrm{z}|$ & [95\% Conf. & Interval] \\
\hline I_lunem & .7181525 & .0515055 & 13.94 & 0.000 & .6172036 & .8191015 \\
\hline public soc l & .6132837 & .1540012 & 3.98 & 0.000 & .3114469 & .9151205 \\
\hline labor_prodg & .2561821 & .0997444 & 2.57 & 0.010 & .0606867 & .4516775 \\
\hline${ }^{-1}$ dtot & -.0094886 & .0722025 & -0.13 & 0.895 & -.1510029 & .1320257 \\
\hline inflation & -.6503701 & .1510527 & -4.31 & 0.000 & -.946428 & -.3543122 \\
\hline long_real_r & .5542817 & .1869979 & 2.96 & 0.003 & .1877724 & .9207909 \\
\hline trāe_e_opēn & .1765634 & .0976091 & 1.81 & 0.070 & -.0147469 & .3678737 \\
\hline popd & .0308561 & .0665197 & 0.46 & 0.643 & -.0995201 & .1612323 \\
\hline
\end{tabular}


Results for Youth unemployment rate:

ivregress $2 \mathrm{sls}$ youth unem2 ( 1 yunem $=12$ yunem 13 yunem) income support labor prodg dtot inflation long_real_r trade_open popd i.id i.year, robust cluster(id)

Instrumental variables (2SLS) regression

$\begin{array}{llr}\text { Number of obs } & = & 375 \\ \text { Wald chi2 }(50) & =2.9 e+05 \\ \text { Prob > chi2 } & =0.0000 \\ \text { R-squared } & =0.9647 \\ \text { Root MSE } & =1.5695\end{array}$

(Std. Err. adjusted for 26 clusters in id)

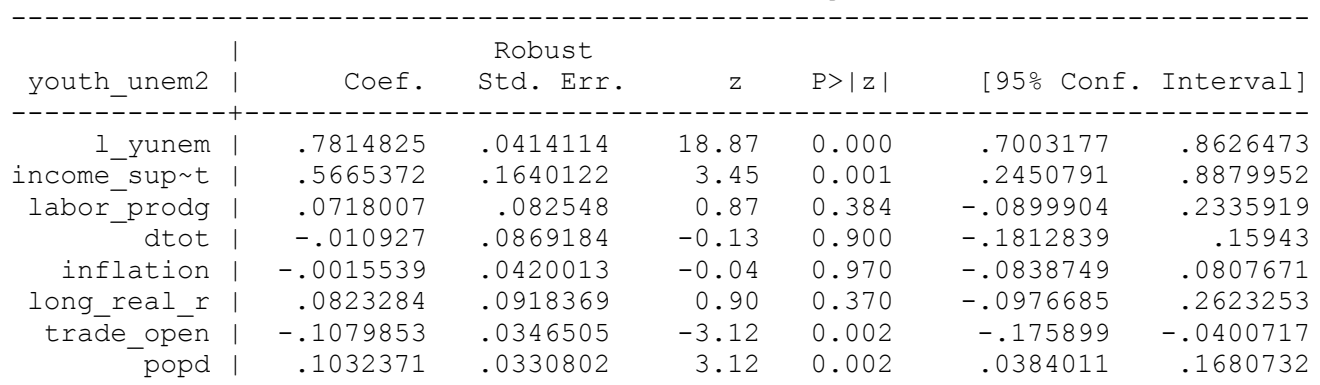

ivregress $2 \mathrm{sls}$ youth unem2 ( 1 yunem $=12$ yunem 13 yunem) pension exp labor prodg dtot inflation long_real_r trade_open popd i.id i.year, robust cluster(id)

Instrumental variables (2SLS) regression

$\begin{array}{llr}\text { Number of obs } & = & 375 \\ \text { Wald chi2 }(50) & =30208.95 \\ \text { Prob > chi2 } & =0.0000 \\ \text { R-squared } & =0.9641 \\ \text { Root MSE } & =1.5824\end{array}$

(Std. Err. adjusted for 26 clusters in id)

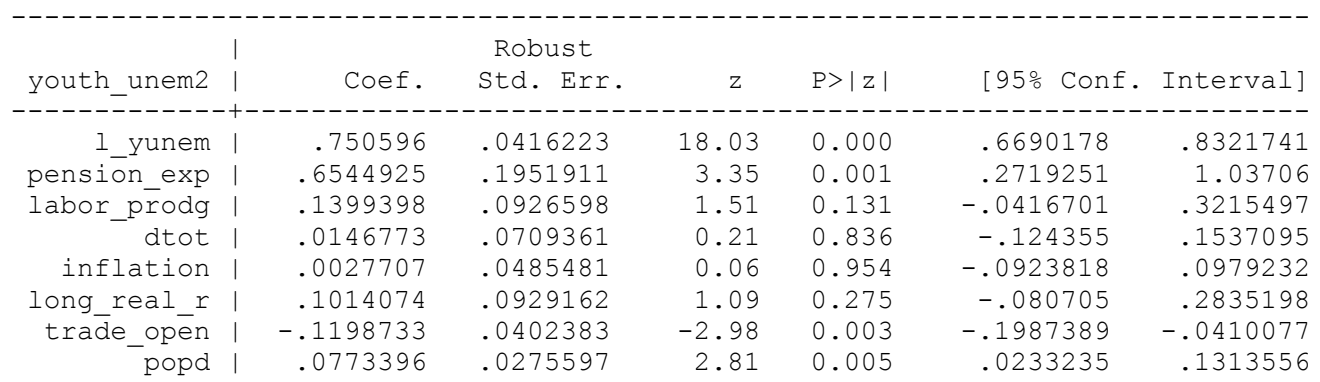

ivregress 2sls youth_unem2 (1_yunem = 12_yunem 13_yunem) health_exp labor_prodg dtot inflation long_real_r trade_open popd i.id i.year, robust cluster(id)

Instrumental variables (2SLS) regression

$\begin{array}{llr}\text { Number of obs } & = & 375 \\ \text { Wald chi2 }(50) & = & 3116.18 \\ \text { Prob > chi2 } & = & 0.0000 \\ \text { R-squared } & =0.9639 \\ \text { Root MSE } & =1.5866\end{array}$

(Std. Err. adjusted for 26 clusters in id)

\begin{tabular}{|c|c|c|c|c|c|c|}
\hline youth_unem2 & Coef. & $\begin{array}{l}\text { Robust } \\
\text { Std. Err. }\end{array}$ & z & $P>|z|$ & [95\% Conf. & Interval] \\
\hline I_yunem & .8008507 & .0358674 & 22.33 & 0.000 & .7305519 & .8711495 \\
\hline health_exp & .6104667 & .3802941 & 1.61 & 0.108 & -.134896 & 1.355829 \\
\hline labor_prodg & .1132283 & .0829629 & 1.36 & 0.172 & -.0493759 & .2758325 \\
\hline dtot & -.0051361 & .0725136 & -0.07 & 0.944 & -.1472602 & .1369881 \\
\hline inflation & -.0237362 & .0447449 & -0.53 & 0.596 & -.1114346 & .0639622 \\
\hline long_real_r & .1010832 & .088689 & 1.14 & 0.254 & -.0727441 & .2749104 \\
\hline trade_open & -.1055579 & .0404467 & -2.61 & 0.009 & -.184832 & -.0262838 \\
\hline
\end{tabular}


\begin{tabular}{l|lllllll} 
popd & .0770716 & .0268769 & 2.87 & 0.004 & .0243938 & .1297494
\end{tabular}

ivregress 2sls youth_unem2 (1_yunem = 12_yunem 13_yunem) otherwelf labor_prodg dtot inflation long_real_ēr trade_open popd i.id i.year, robust cluster(id)

Instrumental variables (2SLS) regression

$\begin{array}{llr}\text { Number of obs } & = & 375 \\ \text { Wald chi2 }(50) & =89033.74 \\ \text { Prob > chi2 } & = & 0.0000 \\ \text { R-squared } & =0.9632 \\ \text { Root MSE } & =1.6018\end{array}$

(Std. Err. adjusted for 26 clusters in id)

\begin{tabular}{|c|c|c|c|c|c|c|}
\hline & & Robust & & & & \\
\hline youth_unem2 & Coef. & Std. Err. & $\mathrm{z}$ & $\mathrm{P}>|z|$ & [95\% Conf. & Interval] \\
\hline 1_yunem & .791093 & .0416233 & 19.01 & 0.000 & .7095128 & .8726731 \\
\hline otherwelf & -.2054234 & .4467246 & -0.46 & 0.646 & -1.080987 & .6701406 \\
\hline labor prodg & .1003547 & .0835089 & 1.20 & 0.229 & -.0633197 & .2640292 \\
\hline dtot & -.0180227 & .0713057 & -0.25 & 0.800 & -.1577793 & .121734 \\
\hline inflation & -.0257165 & .0378916 & -0.68 & 0.497 & -.0999827 & .0485497 \\
\hline long real r & .1097444 & .0921855 & 1.19 & 0.234 & -.0709358 & .2904247 \\
\hline trāe_opēn & -.1371284 & .044551 & -3.08 & 0.002 & -.2244467 & -.0498101 \\
\hline popd & .0862399 & .0406757 & 2.12 & 0.034 & .0065171 & .1659627 \\
\hline
\end{tabular}

ivregress 2sls youth_unem2 (1_yunem = 12_yunem 13_yunem) public_social labor_prodg dtot inflation long_real $\bar{r}$ trade_open popd i.id i.year, robust cluster(id)

Instrumental variables (2SLS) regression Number of obs $=375$

Wald $\operatorname{chi} 2(50)=3769.85$

Prob > chi2 $=0.0000$

$\mathrm{R}$-squared $\quad=0.9643$

Root MSE $\quad=1.5768$

(Std. Err. adjusted for 26 clusters in id)

\begin{tabular}{|c|c|c|c|c|c|c|}
\hline \multirow[b]{2}{*}{ youth_unem2 } & \multicolumn{6}{|c|}{ Robust } \\
\hline & Coef. & Std. Err. & $\mathrm{z}$ & $P>|z|$ & [95\% Conf. & Interval] \\
\hline 1 yunem & .7740472 & .0397045 & 19.50 & 0.000 & .6962278 & .8518667 \\
\hline public soc l & .2469093 & .0724841 & 3.41 & 0.001 & .1048431 & .3889755 \\
\hline labor prodg & .1034618 & .08622 & 1.20 & 0.230 & -.0655262 & .2724498 \\
\hline dtot & .005552 & .0802376 & 0.07 & 0.945 & -.1517109 & .1628149 \\
\hline inflation & .0016986 & .0446789 & 0.04 & 0.970 & -.0858704 & .0892676 \\
\hline long real r & .0888479 & .0916223 & 0.97 & 0.332 & -.0907285 & .2684243 \\
\hline trāe opēn & -.1021094 & .0373676 & -2.73 & 0.006 & -.1753486 & -.0288703 \\
\hline popd & .078719 & .0286959 & 2.74 & 0.006 & .0224761 & .1349619 \\
\hline
\end{tabular}


Mechanism (test the effect of welfare on investment rate):

reg invrate income_support long_real_r inflation trade_open i.id i.year, robust cluster (id)

Linear regression

$\begin{array}{llr}\text { Number of obs } & = & 564 \\ \mathrm{~F}(26, & 27) & \\ \text { Prob }>\mathrm{F} & = & . \\ \text { R-squared } & = & 0.6930 \\ \text { Root MSE } & = & 1.9795\end{array}$

(Std. Err. adjusted for 28 clusters in id)

\begin{tabular}{|c|c|c|c|c|c|c|}
\hline & & Robust & & & & \\
\hline invrate & Coef. & Std. Err. & t & $P>|t|$ & [95\% Conf. & Interval] \\
\hline income sup t & - 4789644 & 2268682 & $-2 \quad 11$ & $\cap \cap 44$ & -9444595 & - 0134693 \\
\hline long real r & -2413778 & .1376528 & -1.75 & 0.091 & - 5238181 & .0410625 \\
\hline inflation & .1206408 & .0958505 & 1.26 & 0.219 & -.0760281 & .3173097 \\
\hline trade_open & -.0317925 & .0469124 & -0.68 & 0.504 & -.1280488 & .0644638 \\
\hline
\end{tabular}

reg invrate pension exp long real r inflation trade open i.id i.year, robust cluster(id) Linear regression

$\begin{array}{llr}\text { Number of obs } & & 562 \\ \mathrm{~F}(26, & 27) & \\ \text { Prob }>\mathrm{F} & = & . \\ \text { R-squared } & = & 0.7059 \\ \text { Root MSE } & = & 1.9309\end{array}$

(Std. Err. adjusted for 28 clusters in id)

\begin{tabular}{|c|c|c|c|c|c|c|}
\hline \multirow{2}{*}{ invrate } & \multicolumn{3}{|c|}{ Robust } & \multirow[b]{2}{*}{$P>|t|$} & \multirow[b]{2}{*}{$95 \%$} & \multirow[b]{2}{*}{ Interval] } \\
\hline & Coef. & Std. Err. & t & & & \\
\hline -ーー-ー-ーー-ー-ーーーー & ---------- & & ----- & ----- & ----------- & ---------- \\
\hline pension exp & -.7907701 & .3079682 & -2.57 & 0.016 & -1.422669 & -.1588717 \\
\hline long_reāl_r & -.2833088 & .1422675 & -1.99 & 0.057 & -.5752175 & .0086 \\
\hline inflation & .157987 & .1010815 & 1.56 & 0.130 & -.0494152 & .3653891 \\
\hline trade open & -.0608208 & .0389391 & -1.56 & 0.130 & -.1407173 & .0190757 \\
\hline
\end{tabular}

reg invrate health exp long real r inflation trade open i.id i.year, robust cluster(id) Linear regression

$\begin{array}{llr}\text { Number of obs } & & 562 \\ \text { F }(26, & 27) & . \\ \text { Prob }>\text { F } & = & . \\ \text { R-squared } & = & 0.6836 \\ \text { Root MSE } & = & 2.0028\end{array}$

(Std. Err. adjusted for 28 clusters in id)

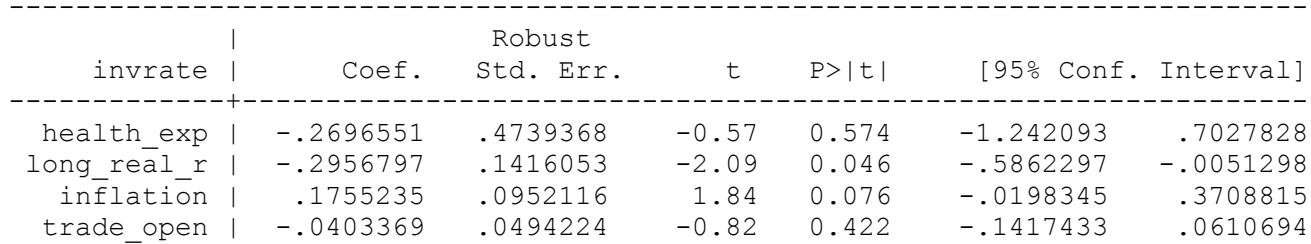

reg invrate otherwelf long_real_r inflation trade_open i.id i.year, robust cluster(id)

Linear regression

$\begin{array}{llr}\text { Number of obs } & & 562 \\ \text { F( 26, 27) } & = & . \\ \text { Prob }>\text { F } & = & . \\ \text { R-squared } & = & 0.6841 \\ \text { Root MSE } & = & 2.0012\end{array}$

(Std. Err. adjusted for 28 clusters in id)

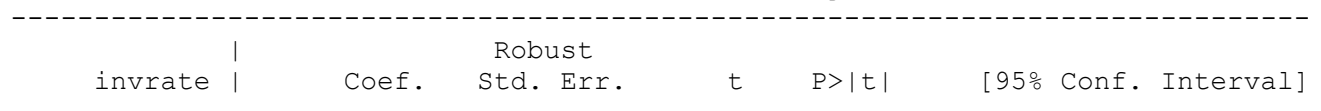




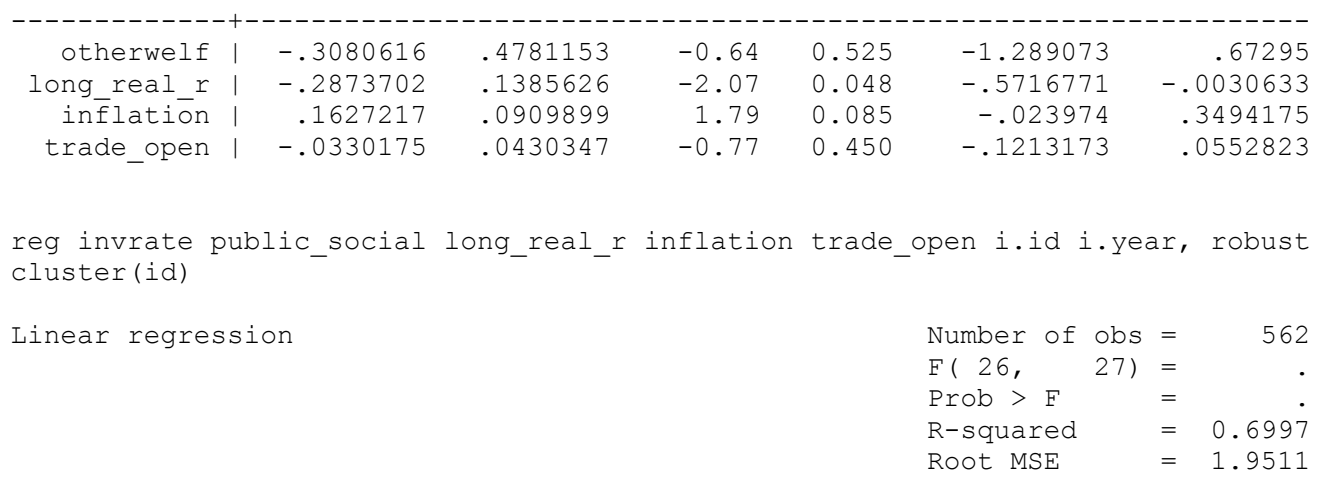

(Std. Err. adjusted for 28 clusters in id)

\begin{tabular}{|c|c|c|c|c|c|c|}
\hline invrate & Coef. & $\begin{array}{l}\text { Robust } \\
\text { Std. Err. }\end{array}$ & t & $P>|t|$ & [95\% Conf. & Interval] \\
\hline public_s & -.2853569 & .1258652 & -2.27 & 0.032 & -.5436108 & -.027102 \\
\hline long real r & -.2539067 & .1339099 & -1.90 & 0.069 & -.5286672 & .0208537 \\
\hline infilation & .1351478 & .0964975 & 1.40 & 0.173 & -.0628487 & .3331442 \\
\hline trade open & -.0548706 & .039083 & -1.40 & 0.172 & -.1350623 & .0253212 \\
\hline
\end{tabular}




\section{Sensitivity analysis}

Adding migrate, replacing labor_prodg with mf_prodg, dtot with ldtot:

IV strength and Endogeneity test again:

quietly reg income support road migrate long real_r mf prodg ldtot inflation trade open popd i.id i.yearl

test road

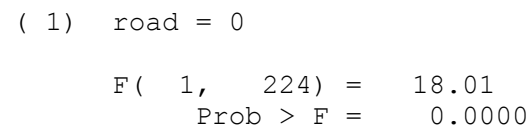

(Std. Err. adjusted for 18 clusters in id)

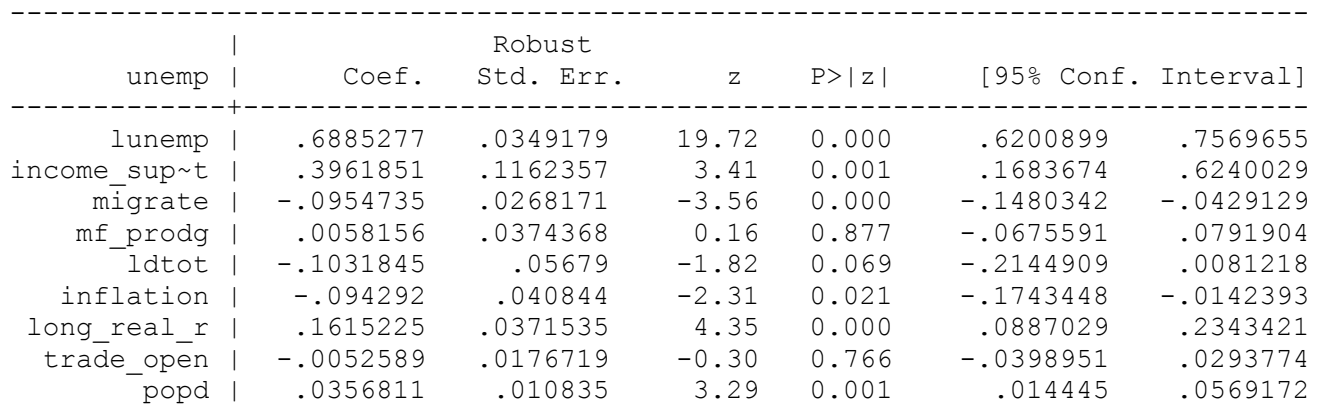


ivregress $2 \mathrm{sls}$ unemp (Iunemp $=12$ unem l3unem) pension exp migrate mf prodg ldtot inflation long_real_r trade_open popdi.id i.year, robust clustēer(id)

Instrumental variables (2SLS) regression Number of obs $=\quad 311$ Wald chi2 $(48)=1473.33$ Prob $>$ chi2 $=0.0000$ R-squared $=0.9666$ Root MSE $\quad=.65579$

(Std. Err. adjusted for 18 clusters in id)

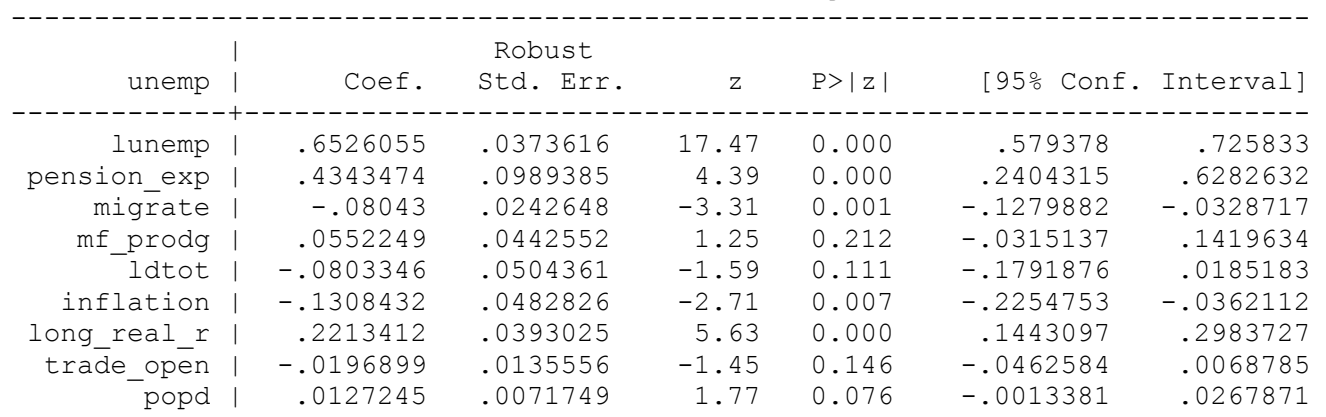

ivregress $2 \mathrm{sls}$ unemp (lunemp $=12$ unem l3unem) health_exp migrate mf_prodg ldtot inflation long real r trade open popd i.id i.year, robust cluster(id)

Instrumental variables (2SLS) regression

$\begin{array}{lrr}\text { Number of obs } & = & 311 \\ \text { Wald chi2 }(48) & = & 431.63 \\ \text { Prob > chi2 } & = & 0.0000 \\ \text { R-squared } & =0.9645 \\ \text { Root MSE } & =.67641\end{array}$

(Std. Err. adjusted for 18 clusters in id)

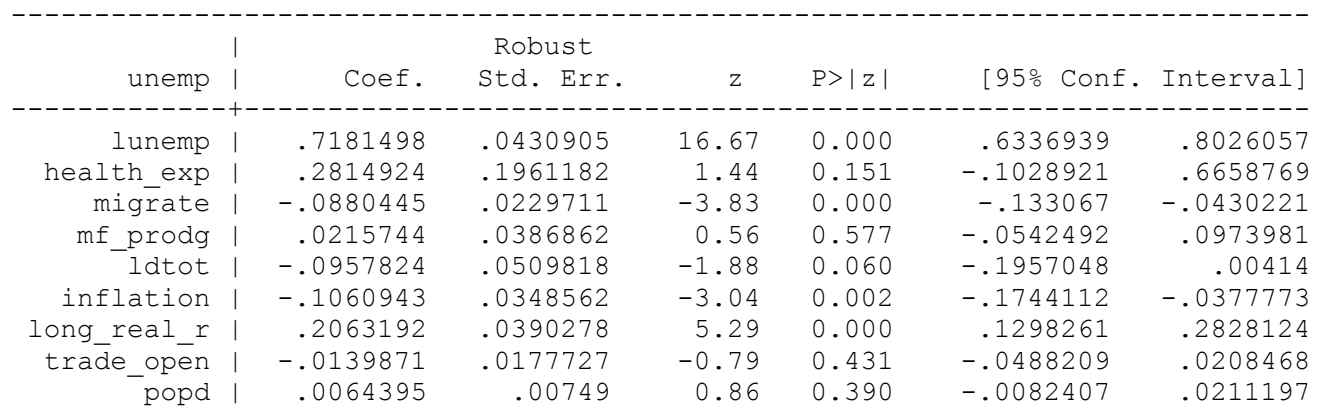

ivregress 2 sls unemp (lunemp =l2unem l3unem) otherwelf migrate mf prodg ldtot inflation long_real_r trade_open popd i.id i.year, robust cluster(id)

Instrumental variables (2SLS) regression

$\begin{array}{llr}\text { Number of obs } & = & 311 \\ \text { Wald chi2 }(48) & = & 1940.10 \\ \text { Prob chi2 } & =0.0000 \\ \text { R-squared } & =0.9632 \\ \text { Root MSE } & =.68874\end{array}$

(Std. Err. adjusted for 18 clusters in id)

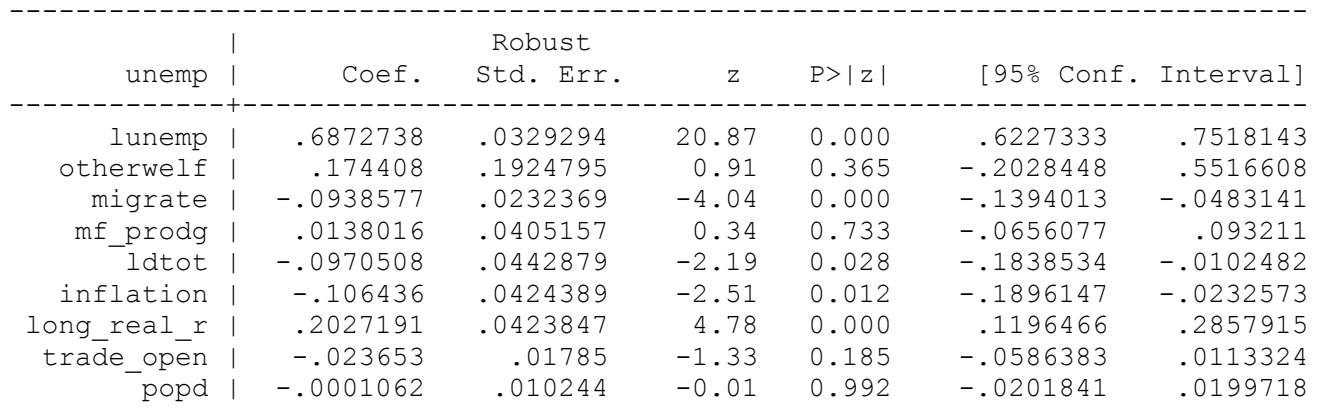


IV strength and Endogeneity test again:

quietly reg public_social road migrate long_real_r mf_prodg ldtot inflation trade_open popd i.id i.yearl

test road

(1) road $=0$

$$
\begin{aligned}
\mathrm{F}(1,224)= & 14.27 \\
\text { Prob }>\mathrm{F}= & 0.0002
\end{aligned}
$$

predict res2, res

quietly reg unemp public_social migrate mf_prodg ldtot inflation long_real_r trade_open popd res2 i.id i.year

test res2

test res2

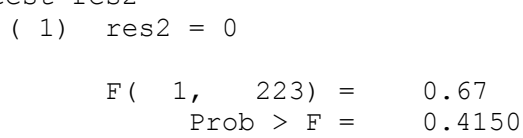

ivregress 2sls unemp (lunemp $=12$ unem l3unem) public_social migrate mf_prodg ldtot inflation long_real_r trade_open popd i.id i.year, robust cluster(id)

Instrumental variables (2SLS) regression

$\begin{array}{lrr}\text { Number of obs } & = & 311 \\ \text { Wald chi2 }(48) & = & 871.66 \\ \text { Prob > chi2 } & = & 0.0000 \\ \text { R-squared } & = & 0.9681 \\ \text { Root MSE } & = & .641\end{array}$

(Std. Err. adjusted for 18 clusters in id)

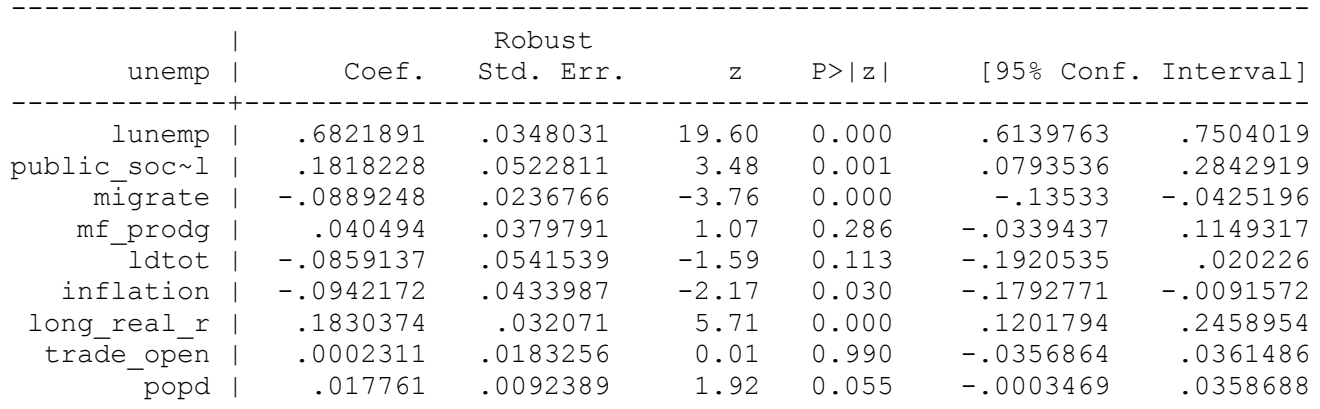

Test the effect of government expenditure of GDP on unemployment rate:

ivregress $2 \mathrm{sls}$ unemp (lunemp $=12$ unem l3unem) govexp migrate mf prodg ldtot inflation long real $r$ trade open popd i.id i.year, robust cluster(id)

Instrumental variables (2SLS) regression

$\begin{array}{lrr}\text { Number of obs } & = & 279 \\ \text { Wald chi2 }(46) & = & 1190.40 \\ \text { Prob chi2 } & =0.0000 \\ \text { R-squared } & =0.9669 \\ \text { Root MSE } & =.66573\end{array}$

(Std. Err. adjusted for 18 clusters in id)

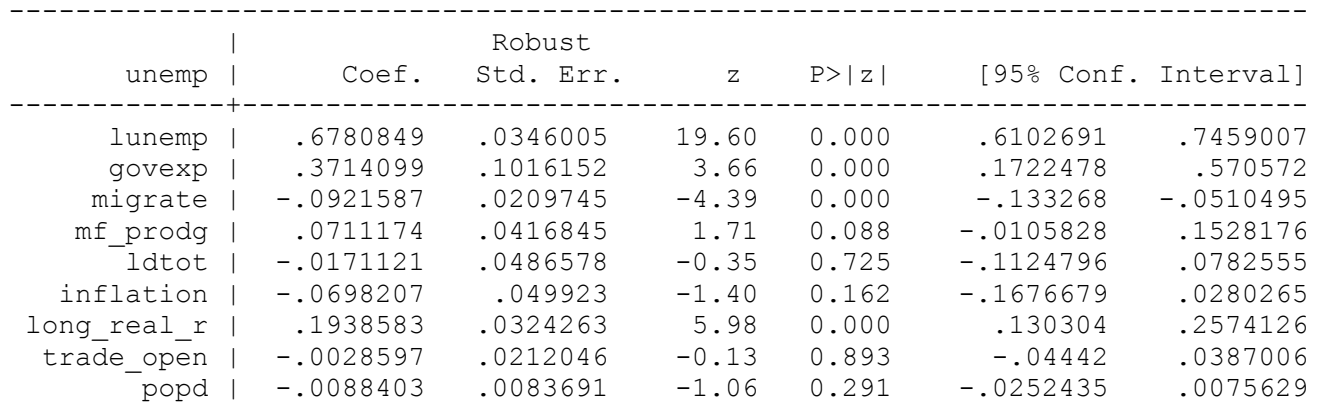

